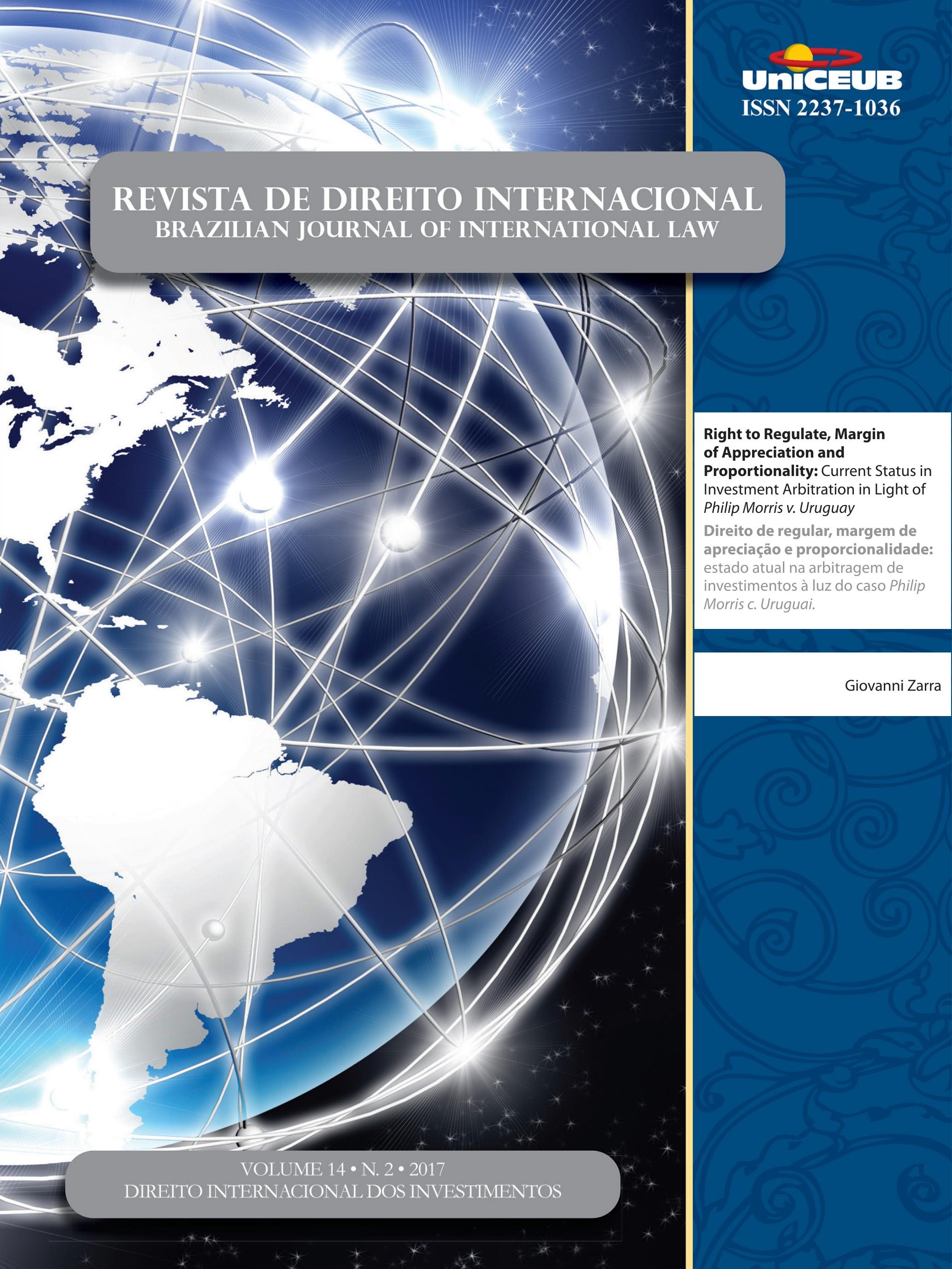




\section{Sumário}

I. Crônicas do Direito Internacional ...............................................1

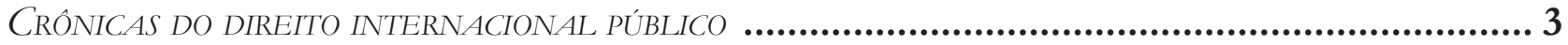

A resolução 2272 (2016) do Conselho de Segurança das Nações Unidas - O POSICIONAMENTO DA ONU FACE ÀS ALEGAÇÕES DE ABUSO E EXPLORAÇÃo SEXUAL POR SUAS

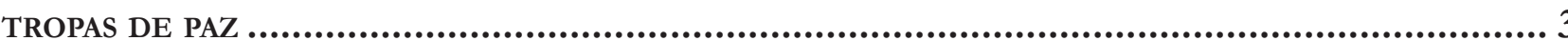

Sarah Dayanna Lacerda Martins Lima

CRÓNICAS DE DiREITo INTERNACIONAL PRIVADO...................................................................

Nadia de Araujo, Marcelo De Nardi, Gustavo Ribeiro, Fabrício Polido e Inez Lopes

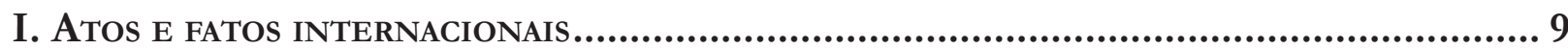

Crônica 1. Novidades de 2017 SObRE CIRCulaÇÃo faCilitada DE SENTENÇAS ESTRANGEIRAS 9

Crônica 2: O Direito Transnacional e os episódios das Carnes.........................................16

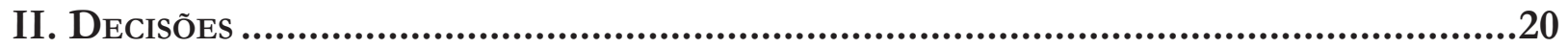

Crônica 3: A Irresistível ForÇa da ORDEM PÚblica E A HOMOLOGaÇÃo DE SENTENÇAS

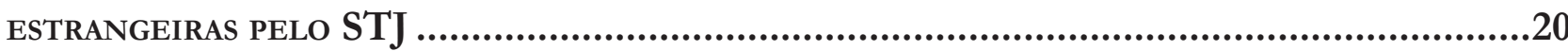

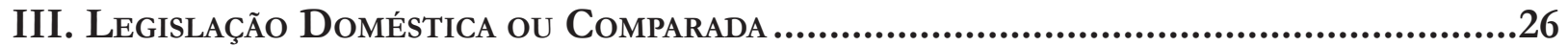

Crônica 4 - Dignidade da pessoa humana e mudança de paradigma da Lei de Migração

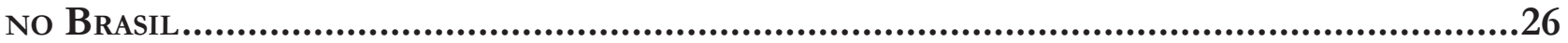

II. Dossiê especial: Direito Internacional dos InVEstimentos ................35

Non-adjudicatory State-State Mechanisms in Investment Dispute Prevention and Dispute Settlement: Joint Interpretations, Filters and Focal Points 
Mapping the Duties of Private Companies in International Investment Law .50 Nitish Monebhurrun

LA LÉGALITÉ DE L'INVESTISSEMENT DEVANT L'ARBITRE INTERNATIONAL: À LA RECHERCHE D'UN POINT D'ÉQUILIBRE .73 Hervé Ascensio

Host STATES AND STATE-STATE INVESTMENT ARBITRATION: STRATEGIES AND CHALlENGES......81 Murilo Otávio Lubamdo de Melo

Right to Regulate, Margin of Appreciation and Proportionality: Current Status in Investment Arbitration in Light of Philip Morris V. Uruguay. .95 Giovanni Zarra

Investments on Disputed Territory: Indispensable Parties and Indispensable Issues....122 Peter Tzeng

The Influence of General Exceptions on the Interpretation of National

Treatment in INTERNATIONAL INVESTMENT LAW. 140 Louis-Marie Chauvel

UMA PRoposta de REFleXão SObRe os ACFIs: Até QUE PONTO O TRATAMENTo de NAÇão MAIS FAVORECIDA PODE MINAR A ESTRATÉGIA POLÍTICA QUE OS EMBASA? 160

Michelle Ratton Sanchez Badin, Daniel Tavela Luis e Mario Alfredo de Oliveira

ECUADOR's 2017 TERMINATION OF TREATIES: HOW NOT TO EXIT THE INTERNATIONAL INVESTMENT REGIME 179

Jose Gustavo Prieto Muñoz

ONE BELT, ONE ROAD: NOVAS INTERFACES ENTRE O COMÉRCIO E OS INVESTIMENTOS INTERNACIONAIS 193

Flávio Marcelo Rodrigues Bruno e Marilda Rosado de Sá Ribeiro

III. Artigos Sobre outros TEMAS..................................................... 214

TolerânCIA E REFugIO: UM ENSAIO A PARTIR Do ACORdo EU-TurQUiA 216 Flávia Cristina Piovesan e Ana Carolina Lopes Olsen 
O TRATAMENTO do APÁtridA NA NOVA LEI DE MIGRAÇÃo: ENTRE AVANÇOS E RETROCESSOS...237 Jahyr-Philippe Bichara

O caráter humanista da Lei de Migrações: aVAnços da Lei N. 13.445/2017 E Os desafios DA REGULAMENTAÇÃO. 254 Marcelo Dias Varella, Clarice G. Oliveira, Mariana S.C. Oliveira e Adriana P. Ligiero

Reform of the United Nations Security Council: The Emperor Has No Clothes.268 Ljubo Runjic

A IDEIA DE QUe os LATINO-AMERICANOS PREFEREM O AUTORITARISMO À DEMOCRACIA À luz da reinterpretação dos Critérios do Programa das Nações Unidas para o DesenVolvimento 286

Gina Marcilio Pompeu e Ana Araújo Ximenes Teixeira

A PRoteção da ORIENTAÇÃo SEXUAL E IDENTIDAdE DE GÊNERO DIVERSAS NA CORTE PENAL internacional: Entre Realpolitiks E Os Direitos Humanos

Gustavo Bussmann Ferreira

A desnacionalização e as violações de direitos humanos na República Dominicana. 331 Daniela Menengoti Gonçalves Ribeiro e Rodrigo Ichikawa Claro Silva

CompetênCia do TPI no Caso do ATAque ao hospital de Kunduz: uma análise ENVOLVENDO A JURISDiÇÃo do TPI EM RELAÇÃO A NACIONAIS DE EsTAdOS NÃO-PARTE do Estatuto DE Roma

Filipe Augusto Silva e Renata Mantovani de Lima

A CRIMINALIZAÇÃo DOS IMIGRANTES EM SITUAÇÃo IRREGULAR NA ITÁliA: BIOPOLÍtica E DIREITO PENAL DO AUTOR.

Maiquel Angelo Dezordi Wermuth e Jeannine Tonetto de Aguiar

The New Rules On Trade And Environment Linkage In Preferential Trade Agreements

Alberto do Amaral Júnior e Alebe Linhares Mesquita

Beyond THE Border between the North and the South: towards a Decolonization of EPISTEMOLOGIES AND FIELDS OF RESEARCH ON MERCOSUR 
A aplicabilidade da Convenção de Montreal no direito brasileiro.

Aziz Tuffi Saliba e Alexandre Rodrigues de Souza

REgIME DE TRANSPARÊNCIA FISCAL NA TRIBUTAÇÃo DOS LUCROS AUFERIDOS NO EXTERIOR (CFC RULES): LACUNAS E CONFLITOS NO DIREITO BRASILEIRO

Paulo Rosenblatt e Rodrigo Torres Pimenta Cabral

As Regras Brasileiras de Tributação de Controladas e Coligadas no Exterior: verdadeiras Controlled Foreign Company (CFC) Rules? .......................................465

Melina de Souza Rocha Lukic e Amanda Almeida Muniz

O RETORNO DE BENS CULTURAIS

Aziz Saliba e Alice Lopes Fabris

Direitos culturais e Nações Unidas: uma análise a partir da Declaração Sobre a eliminação de Todas as Formas de Intolerância e Discriminação Baseadas na Religião OU NA CRENÇA

Leilane Serratine Grubba e Márcio Ricardo Staffen

OS REFLEXOS DA PROTEÇÃO INTERNACIONAL DA PROPRIEDADE INTELECTUAL PARA O DESENVOLVIMENTO INTERNO: UMA ANÁLISE SOBRE O SISTEMA PATENTÁRIO BRASILEIRO E A TRANSFERÊNCIA DE TECNOLOGIA

Michele M. Segala e Isabel Christine S. De Gregori

O CASO HIPOTÉTICO DA MORTE DO EMBAIXADOR FRANCÊS NA ESPANHA: DUAS ESPÉCIES DE IUS gentium em Francisco de Vitoria

Rafael Zelesco Barretto

De volta À BeVilaqua: anÁlise ECONÔMICA dA APLICAÇão do ART. $9^{\circ}$ DA LINDB Às OBRIGAÇÕES CIVIS CONTRATUAIS

Danielle Cristina Lanius e Ivo Teixeira Gico Jr 


\title{
Right to Regulate, Margin of Appreciation and Proportionality: Current Status in Investment Arbitration in Light of Philip Morris v. Uruguay*
}

\author{
Direito de regular, margem de apreciação e \\ proporcionalidade: estado atual na arbitragem \\ de investimentos à luz do caso Philip Morris c. \\ Uruguai
}

Giovanni Zarra**

\section{Abstract}

Starting from the recent Philip Morris v. Uruguay award, this article tries to analyse the current status in investment arbitration of certain doctrines (and/or principles) which are adopted by arbitral tribunals in order to give due weight to state interests. The reference applies to the concepts of the right to regulate and of the margin of appreciation as well as to the principle of proportionality. It will be argued that the right to regulate, which is today receiving growing attention by arbitrators, scholars and treaty drafters, still does not have the customary status which would entitle tribunals to apply it in the absence of a normative basis. Also the margin of appreciation, as technically developed by the European Court of Human Rights, cannot find a place in investor-State disputes due to the very different framework in which arbitral tribunals operate if compared to the ECtHR. However, the principle of proportionality can offer a valuable legal tool to arbitrators entitling them to pay due deference with regard to state sovereignty.

Keywords: Investment arbitration. Indirect expropriation. Fair and equitable treatment. Proportionality. Police powers. Right to regulate (or power to regulate). Margin of appreciation. Deference. Sovereignty of the States.

\section{Resumo}

A partir da recente sentença arbitral Philip Morris v. Uruguai, este artigo analisa o estado atual de certas doutrinas (e / ou princípios) que são adotados pelos tribunais arbitrais para dar devido peso dos interesses do Estado na arbitragem de investimento. A referência aplica-se aos conceitos de direito de regular e à margem de apreciação, bem como ao princípio de proporcionalidade. Argumenta-se que o direito de regular, que está hoje recebendo crescente atenção dos árbitros, estudiosos do direito dos investimentos e redatores de tratados, ainda assim não tem o valor consuetudinário que permitiria a sua aplicação pelos tribunais na ausência de uma base normativa. Também a margem de apreciação, como tem sido tecnicamente de-

\footnotetext{
** Adjunct Professor of Private International Law and International Litigation, University of Naples Federico II. The Author wishes to thank Prof. Fulvio Maria Palombino for the precious support received while writing this work and the anonymous referees, whose suggestions have substantially improved the paper. E-mail: g.zarra@hotmail.it

Recebido em 01/05/2017 Aprovado em 25/07/2017
} 
senvolvida pela Corte Europeia de Direitos Humanos, não pode encontrar um papel em disputas entre investidores e Estados devido ao quadro muito diferente em que os tribunais arbitrais operam. No entanto, o princípio de proporcionalidade pode oferecer uma valiosa ferramenta legal aos árbitros, permitindo-os considerar devidamente a soberania do Estado.

Palavras-chave: arbitragem; investimentos; proporcionalidade; poder de polícia; direito de regular.

\section{INTRODUCTION}

International investment arbitration has been strongly criticized for not being adequately protective of the general interests of States and for being overly protective of investors' rights. ${ }^{1}$ Arbitrators have been accused of interpreting and applying the standards of treatment set forth in Bilateral Investment Treaties (BITs) in a pro-investor manner only. ${ }^{2}$ Not by mere coincidence, indeed, there is a large body of literature ${ }^{3}$ regarding the

1 See, inter alia, HOBER, Kay. Does Investment Arbitration Have a Future?. In: BUNGENBERG Marc et al. (Ed.). International Investment Law. Munich: C.H. Beck, 2015; VAN HARTEN, Gus. Investment Treaty Arbitration and Public Law. Oxford: Oxford University Press, 2007. p. 1; GIARDINA, Andrea. L'arbitrato internazionale in materia di investimenti: impetuosi sviluppi e qualche problema. In: BOSCHIERO, Nerina; LUZZATTO, Riccardo. (Ed.). I rapporti economici internazionali e l'evoluzione del loro regime giuridico. Napoli: Editoriale Scientifica, 2008. p. 319; FRANCK, Susan. The Legitimacy Crisis in Investment Treaty Arbitration: Privatizing Public International Law Through Inconstistent Decisions. Fordham Law Review, p. 1521, 2005; MARKERT, Lars. The Crucial Question of Future Investment Treaties: Balancing Investors' Rights and Regulatory Interests of Host States. European Yearbook of International Economic Law, p. 145, 2011; EL BOUDOUHI, Saida. L'intéret general et les règles substantielles de protection des investissements. Annuaire français de droit international, v. 51, p. 542, 2005; COLLINS, David. The line of equilibrium: improving the legitimacy of investment treaty arbitration through the application of the WTO's general exceptions. Arbitration International, v. 32, p. 575, 2016; PAVONI, Riccardo. Environmental Rights, Sustainable Development, and InvestorState Case Law: A Critical Appraisal. In: DUPUY, Pierre-Marie; PETERSMANN, Enst-Ulrich; FRANCIONI, Francesco. (Ed.). Human Rights in International Investment Law and Arbitration. Oxford University Press, 2009. p. 525.

2 See the debate and the related analysis contained in SCHULTZ, Thomas; DUPONT, Cédric. Investment Arbitration: Promoting the Rule of Law or Over-Empowering Investors? A Quantitative Empirical Study. European Journal of International Law, v. 25, p. 1147, 2014. See also KOSKENNIEMI, Martti. It's not the Cases, It's the System. The Journal of World Investment \& Trade, v. 18, p. 343, 2017. 3 See, inter alia, ACCONCI, Pia. The integration of non-investment concerns as an opportunity for the modernization of inter- ways in which arbitral tribunals could properly balance the interests at stake in investment disputes and ensure that States' concerns are duly taken into account in final decisions. The main issue faced by these scholarly works regards the fact that several existing BITs have concise wordings which often do not seem to outwardly justify such a balanced reading.

Recent arbitral practice, however, shows a willingness to react to criticisms. Various awards ${ }^{4}$ contain several references to the necessity of applying standards of treatment in a way that protects the so-called non-commercial values (i.e. values not pertaining to the protection of property but relating to the safeguard of other essential interests such as environment and human health). ${ }^{5}$ Tribunals have started giving due weight to States' reasons for the enactment of measures that can cause damage to foreign investors. ${ }^{6}$ Particular importance appears to have been given, in this regard, to some concepts that are only recently taking shape in arbitral practice, such as the right to regulate, the margin of appreciation and the principle of proportionali-

national investment law: is a multilateral approach desirable?. In: SACERDOTI, Giorgio et al. (Ed.). General Interests of Host States in International Investment Law. Cambridge University Press, 2014. p. 165; TANZI, Attila. On Balancing Foreign Investment Treaties with Public Interests in Recent Arbitration Case Law in the Public Utilities Sector. The Law and Practice of International Courts and Tribunals, v. 11, p. 47, 2012; WAGNER, Markus. Regulatory Space in International Trade Law and International Investment Law. University of Pennsylvania Journal of International Law, v. 36, p. 1, 2015; PUMA, Giuseppe. Human Rights and Investment Law: Attempts at Harmonization Through a Difficult Dialogue Between Arbitrators and Human Rights Tribunals. In: ARCARI, Maurizio; BALMOND, Louis. (Ed.). Judicial Dialogue in the International Legal Order. Editoriale Scientifica, 2014. p. 193; VADI, Valentina; GRUSZCZYNSKI, Lukasz. Sandards of Review in International Investment Law and Arbitration: Multilevel Governance and the Commonweal. Journal of International Economic Law, v. 16, p. 613, 2013.

4 See, e.g., Urbaser S.A. and Consorcio de Aguas Bilbao Biøkaia, Bilbao Biqkeaia Ur Parzerguoa v. The Argentine Republic, ICSID Case No. ARB/07/26, Award. 02/12/2016, paras. 618-625; Chemtura Corporation v. Government of Canada, NAFTA/UNCITRAL, Award, 02/08/ 2010; Methanex Corporation v. United States of America, NAFTA/UNCITRAL, Award, 03/08/2005.

5 DI BENEDETTO, Saverio. International Investment Law and the Environment. Edward Elgar, 2013. p. 16-17; MONHEBURRUN, Nitish. Is investment arbitration an appropriate venue for environmental issues? A Latin American perspective. Brazilian Journal of International Law, v. 10, p. 196, 2013; FOOTER, Mary. BITS and Pieces: Social and Environmental Protection in the Regulation of Foreign Investment. Michigan State Journal of International Law, v. 18, p. 33, 2009.

6 See BERNARDINI, Piero. Reforming Investor-State Dispute Settlement: The Need to Balance Both Parties' Interests. ICSID Review - FILJ, v. 32, p. 38, 2017. 
ty. While varying in their content, all of these concepts allow arbitrators to interpret standards of treatment of foreign investors in a way that grants a certain degree of deference to State actions. The right to regulate (also referred to as the "power to regulate" or the "State police powers doctrine") has been defined as "the legal right exceptionally permitting the host $[\mathrm{S}]$ tate to regulate in derogation of international commitments it has undertaken by means of an investment agreement without incurring a duty to compensate" ${ }^{\prime 7}$ in the presence of State interests that are of vital importance for the population involved. The margin of appreciation is a doctrine developed by the European Court of Human Rights (ECtHR). It consists in the recognition - in the presence of specific requirements - of a certain degree of discretion to Contracting Parties by the Court when evaluating the legitimacy of limitations to rights set forth in the European Convention of Human Rights (ECHR) imposed by States for reasons of public interest. ${ }^{8}$ Finally, in the context of investment arbitration, the principle of proportionality (which, as we will see below, is recognized as a general principle of international law by a large number of authors) consists in the search for a balance between the State's interests protected through a governmental action and the degree of damage to investors' rights which are going to be affected by such a measure. ${ }^{?}$

7 TITI, Aikaterini. The Right to Regulate in International Investment Law. Oxford: Hart, Nomos, Dike, 2014. p. 33. In this regard, it is to be noted that it is questionable whether the police powers doctrine applies to all standards under an investment treaty, or only the expropriation standard. Howerver, in this article the doctrine is discussed only in relation to expropriation (which is the standard in relation to which the Philip Morris Tribunal made recourse to the right to regulate).

8 PALOMBINO, Fulvio Maria. Laicità dello Stato ed esposizione del crocifisso nella sentenza della Corte europea dei diritti dell'uomo nel caso Lautsi. Rivista di diritto internazionale, v. 93, p. 137-138, 2010. See also BENVENISTI, Eyal. Margin of Appreciation, Consensus and Universal Standards. New York University Journal of International Law and Politics, v. 31, p. 843, 1999; GREER, Steven. The margin of appreciation: interpretation and discretion under the European Convention on Human Rights. Strasbourg: Council of Europe Publishing, 2000; FEINGOLD, Cora. Doctrine of Margin of Appreciation and the European Convention on Human Rights. Notre Dame Law Review, v. 53, p. 90, 1977; HUTCHINSON, Michael. The Margin of Appreciation Doctrine in the European Court of Human Rights. The Internatinoal and Comparative Law Quarterly, v. 48, p. 638, 1999; SAUL, Matthew. The European Court of Human Rights' Margin of Appreciation and the Processes of National Parliaments. Human Rights Law Review, v. 15, p. 745, 2015.

9 For an in-depth analysis of the legal foundation and of the content of the principle of proportionality see PALOMBINO, Fulvio Maria. Il trattamento giusto ed equo degli investimenti stranieri, Il
The purpose of the present article is to understand whether and to what extent the above-mentioned doctrines, which are all tools employed by international arbitrators in order to show deference towards States' sovereignty, apply in international investment arbitration and which one among them as a consequence can be applied by arbitrators in order to pay due respect to choices made by States in matters of public interest. Such an analysis will start (second Section) from the award and the appended dissenting opinion recently issued in the Philip Morris v. Uruguay case. This dispute dealt with all the above concepts and is thus a good starting point to describe the state of art of the application of such concepts in investment arbitration. On the basis of the case study offered by the Philip Morris award, ${ }^{10}$ the article then proceeds to analyse in greater detail the applicability of the power to regulate to cases of indirect expropriation (third Section) and of the margin of appreciation doctrine in cases involving the fair and equitable treatment standard (fourth Section). It will be demonstrated that the analysis made by arbitral tribunals turns out to be mainly based on the principle of proportionality - which, as it has been demonstrated in scholarship, is almost certainly a primary source of international law. Hence, most attention should be paid to such a principle in arbitrators' reasoning in order to reach the goal of being deferent towards State practice instead of relying, as the Philip Morris Tribunal did, on doctrines the legal status of which is still uncertain in international law.

\section{Philip Morkis v. Uruguay and the Recent Deferential Approach Endorsed by Arbitral Tribunals}

Mulino. 2012 (an English edition of the book, Fair and Equitable Treatment and the Fabric of General Principles, Asser - Springer, 2017, is forthcoming). Other relevant texts analysing the principle and its possible legal foundation are HENCKELS, Caroline. Proportionality and Deference in Investor-State Arbitration. Cambridge University Press, 2015; BUCHELER, Gebhard. Proportionality in InvestorState Arbitration. Oxford University Press, 2015; CANNIZZARO, Enzo. Il principio di proporzionalità nell'ordinamento Internażionale. Giuffrè, 2000.

10 Philip Morris Brands SÀRL, Philip Morris Products S.A. and Abal Hermanos S.A. v. Oriental Republic of Uruguay, ICSID Case No. Arb/10/7, Award, 08/07/2016. The Tribunal was composed of Prof. Piero Bernardini (President), Judge James Crawford and Mr. Gary Born. 


\subsection{The Dispute and the Claims}

The award issued on 8 July 2016 in the well-known Philip Morris v. Uruguay dispute is one of the clearest examples of the recent tendency to give particular weight to State reasons. ${ }^{11}$ The dispute was brought under the terms of the Switzerland - Uruguay BIT ${ }^{12}$ and concerned two measures enacted by Uruguay which negatively affected tobacco industries operating in that Country. The first of them, named "single presentation requirement" precluded tobacco manufacturers from marketing more than one variant of cigarettes per brand family. ${ }^{13}$ The second measure, entitled " $80 / 80$ regulation", increased the size of graphic health warnings appearing on cigarettes packages from $50 \%$ to $80 \%{ }^{14}$ As a consequence, only $20 \%$ of cigarettes packs remained available for trademarks, logos and other information.

According to the Claimants, the challenged measures - inter alia - violated the obligations not to indirectly expropriate foreign investments (Art. 5 of the BIT) ${ }^{15}$ and to grant fair and equitable treatment to such investments (Art. 3(2) of the BIT) ${ }^{16}$ With regard to the former violation, the Claimants stated that the measures substantially deprived the investment of its value rendering it a non-profitable business, something that

11 For earlier comments to the decision see VOON, Tania. Philip Morris v. Uruguay: Implications for Public Health. Journal of World Investment and Trade, v. 18, p. 320, 2017; MITCHELL, Kate. Philip Morris v. Uruguay: An Affirmation of 'Police Powers' and 'Regulatory Power in the Public Interest' in International Investment Law. EJIL: Talk, 2016.

12 Agreement between the Swiss Confederation and the Oriental Republic of Uruguay on the Reciprocal Promotion and Protection of Investments, signed on 07/10/1988 and in force since 22/04/1991.

13 Prior to the measure, Philip Morris (through its subsidiary Abal) sold in Uruguay various variants of cigarettes, such as Marlboro Gold, Marlboro Red, Marlboro Silver etc. Pursuant to the measures only one variant can be sold. See Philip Morris award, n. 10 above, para. 10.

14 See Philip Morris award, para. 9 and

15 Art. 5 of the Switzerland - Uruguay BIT: "Neither of the Contracting Parties shall take, either directly or indirectly, measures of expropriation, nationalization or any other measure having the same nature or the same effect against investments belonging to investors of the other Contracting Party, unless the measures are taken for the public benefit as established by law, on a non-discriminatory basis, and under due process of law, and provided that provisions be made for effective and adequate compensation".

16 Art. 3(2) of the Switzerland - Uruguay BIT: "Each Contracting Party shall ensure fair and equitable treatment within its territory of the investments of the investors of the other Contracting Party". is considered to be tantamount to expropriation (so-called indirect expropriation) and falls under the protection of the BIT. ${ }^{17}$ Concerning the latter violation, Philip Morris averred that: (i) there is no proof that the measures served a public purpose and, as a consequence, they are arbitrary; (ii) the measures undermined the Claimants' legitimate expectation to use and enjoy their investment; and (iii) the measures destroyed the legal stability that Uruguay pledged in the BIT and on which the Claimants relied.

Uruguay replied claiming that the measures were enacted with the aim of protecting human health, in accordance with the Uruguayan Constitution and the international commitments assumed by Uruguay within the framework of the World Health Organization (WHO) ${ }^{18}$ Moreover, both regulations were applied in a non-discriminatory manner to all tobacco companies and they amounted to a reasonable, good faith exercise of Uruguay's sovereign prerogatives. ${ }^{19}$ The single presentation requirement was enacted with the purpose of avoiding that consumers could think that certain variants of cigarettes are safer than others, while the $80 / 80$ regulation was adopted to increase consumer awareness of the health risks related to tobacco consumption. ${ }^{20}$ Both the measures being legitimate exercises of sovereign power, in the Respondent's view they cannot amount to a violation of the investment treaty's standards. ${ }^{21}$

\subsection{The Tribunal's Decision and the Dissenting Opinion Regarding the FET Violation}

Both of the claims were rejected by the Tribunal. With regard to the indirect expropriation claim, the Tribunal firstly noted that the Claimants' investment was not substantially deprived of its value. In the Tribunal's view, this factor, alone, would have been sufficient to dismiss the claim. However, the arbitrators introduced

17 On the concept of indirect expropriation see, inter alia, DOLZER, Rudolf. Indirect Expropriation: New Developments?. NYU Environmental Law Journal, v. 64, p. 64, 2002-2003; DE LUCA, Anna. Indirect expropriations and regulatory takings: what role for the "legitimate expectations" of foreign investors?. In: SACERDOTI, Giorgio et al. (Ed.). General Interests of Host States in International Investment Law. Cambridge University Press, 2014.

18 See para. 361

19 See para. 355.

20 Para. 357 and

21 See paras. 216-217. 
"an additional reason in support of the same conclusion [...]. In the Tribunal's view, the adoption of the [c] hallenged [m] easures by Uruguay was a valid exercise of the State's police powers, with the consequence of defeating the claim for expropriation under Article 5(1) of the BIT"'.22 According to the Panel, the power to regulate is a customary rule of international law and the BIT should be interpreted in accordance with it, pursuant to the provision of Art. 31(3)(c) of the 1969 Vienna Convention on the Law of Treaties (VCLT), which sets forth that treaty provisions shall be interpreted in the light of any relevant rules of international law applicable to the relations between the parties, including public international law. In the Tribunal's view, the customary nature of the police powers doctrine is proved by various factors. The first of them is Article 10(5) of the 1961 Harvard Draft Convention on the International Responsibility of States for Injury to Aliens, which states that "[a]n uncompensated taking of property of an alien or a deprivation of the use or enjoyment of property of an alien which results from [...] the action of the competent authorities of the State in the maintenance of public order, health, or morality, shall not be considered wrongful" (provided that it is non-discriminatory). ${ }^{23}$ According to the Tribunal, the doctrine has been endorsed also in the Third Restatement of the Foreign Relations Law of the United States of 1987, which provides that "[a] State is not responsible for loss of property or for other economic disadvantage resulting from bona fide general taxation, regulation, forfeiture for crime, or other action of the kind that is commonly accepted as within the police powers of states, if it is not discriminatory". ${ }^{24}$ Third, the Tribunal mentioned the OECD working paper on "Indirect Expropriation and the Right to Regulate", stating that "it is an accepted principle of customary international law that where economic injury results from a bona fide non-discriminatory regulation within the police power of the State, compensation is not required". ${ }^{25}$ Finally, the customary status of the doctrine would be pro-

22 Philip Morris award, n. 10 above, para. 287.

23 Convention on the international responsibility of states for injuries to aliens; draft no. 12, drafted by Louis B Sohn and Richard Baxter of the Harvard Law School in 1961.

24 American Law Institute, Restatement (Third) Foreign Relations of the United States, v. 1, para. 712, comment (g), 1987.

25 Philip Morris award, n. 10 above, para. 294, mentioning YANNACA-SMALL, Catherine, "Indirect Expropriation" and the "Right to Regulate" in International Investment Law, OECD Working Papers on International Investment Number 2004/4, p. 5, 2004. ven by various investment awards, including Tecmed, ${ }^{26}$ Saluka, ${ }^{27}$ Methanex ${ }^{28}$ and Chemtura, ${ }^{29}$ as well as by various provisions of recent investment treaties (the content of which will be better described below), including the 2004 and 2012 US Model BITs, ${ }^{30}$ the 2004 Canada Model BIT, ${ }^{31}$ the EU-Canada Comprehensive Economic and Trade Agreement (CETA) ${ }^{32}$ and the EU-Singapore Free Trade Agreement (FTA). ${ }^{33}$

The Tribunal concluded that Uruguay's measures had been adopted bona fide for the purpose of protecting public welfare, were non-discriminatory and were proportionate. They were not to be considered as an expropriation and, hence, did not give to the Claimants any right to be compensated, despite the existence of a negative impact on their business. ${ }^{34}$

As to the alleged violation of the fair and equitable treatment, the Tribunal recalled that both measures had been implemented for the protection of public health and explained that, in making public policy determinations, Uruguay enjoyed a certain margin of appreciation, as it happens in the ECHR context for States whi$\mathrm{ch}$, in order to protect a public interest, depart from the protection of a conventional right. ${ }^{35}$ According to the

26 Tecnicas Medioambientales Tecmed S.A. v. The United Mexican States, UNCITRAL, Award, 29/05/2003, para. 119.

27 Saluka Investments B.V. v. The Czech Republic, UNCITRAL, Partial Award, 17/03/2006, para. 255, 260, 262.

28 See n. 4 above, Part IV, Ch. D, para. 7.

29 See n. 4 above, para. 366.

30 See Art. 12(3), which states that, in matters regarding the protection of the environment, "[t]he Parties recognize that each Party retains the right to exercise discretion with respect to regulatory, compliance, investigatory, and prosecutorial matters, and to make decisions regarding the allocation of resources to enforcement with respect to other environmental matters determined to have higher priorities. Accordingly, the Parties understand that a Party is in compliance with paragraph 2 where a course of action or inaction reflects a reasonable exercise of such discretion, or results from a bona fide decision regarding the allocation of resources".

31 See Annex B.13(1)(c), which states that "[e]xcept in rare circumstances, such as when a measure or series of measures are so severe in the light of their purpose that they cannot be reasonably viewed as having been adopted and applied in good faith, non-discriminatory measures of a Party that are designed and applied to protect legitimate public welfare objectives, such as health, safety and the environment, do not constitute indirect expropriation".

32 See CETA, Annex 8-A (Expropriation), Art. 3. The CETA consolidated text is available at http://trade.ec.europa.eu/doclib/ docs/2014/september/tradoc_152806.pdf.

33 See EU-Singapore FTA, Annex 9-A (expropriation), Art. 2. The EU-Singapore FTA authentic text as of May 2015 is available at http://trade.ec.europa.eu/doclib/press/index.cfm?id=961.

34 See Philip Morris award, n. 10 above, para. 305

35 See Philip Morris award para. 398 
Tribunal " $t$ ]he responsibility for public health measures rests with the government and investment tribunals should pay great deference to governmental judgments of national needs in matters such as the protection of public health. In such cases respect is due to the discretionary exercise of sovereign power, not made irrationally and not exercised in bad faith [...] involving many complex factors" (citations omitted). ${ }^{36}$ In light of this approach, the majority of the Tribunal did not find it necessary to decide whether the measures were actually able to reach the goals that were originally intended by the State, being sufficient that they were a good faith attempt to address a real public health concern. ${ }^{37}$ In the majority's view "[h]ow a government requires the acknowledged health risks of products, such as tobacco, to be communicated to the persons at risk is a matter of public policy to be left to the appreciation of the regulatory authority". 38

In addition, the exercise of the State's normal regulatory power in the pursuance of a public interest should not be seen as a violation of legitimate expectations, as long as there is no violation of specific undertakings assumed by the State. "Manufacturers and distributors of harmful products such as cigarettes can have no expectation that new and more onerous regulations will not be imposed, and certainly no commitments of any kind were given by Uruguay to the Claimants". ${ }^{39}$

As regards the alleged violation of the fair and equitable treatment standard, however, Arbitrator Gary Born issued a strongly dissenting opinion, stating that - notwithstanding the undisputed sovereign regulatory authority of Uruguay $^{40}$ - the measures lacked proportionality, i.e. they are extremely burdensome for investors in light of the goals for which they have been enacted. This consideration is mainly based on the fact that there is no evidence of any prior study by Uruguay as to the adequacy of the measures to reach their objectives. Moreover, Born argued that the recourse to the margin of appreciation doctrine developed in the ECtHR ju-

\footnotetext{
36 See Philip Morris award para. 399.

37 See Philip Morris award para. 409.

38 See Philip Morris award para. 419

39 See Philip Morris award para. 429. This approach to legitimate expectations reflects the theory of legitimate expectations by induction, perfectly explained by PALOMBINO, n. 9 above, p. 139 See, in this regard, Section 4 below.

40 See, in this regard, Born's Dissenting Opinion appended to the Philip Morris award, para. 90.
}

risprudence is ill-suited for investment disputes. ${ }^{41} \mathrm{With}$ respect to the protection of propriety (as protected by Art. 1 of Protocol 1 of the ECHR), ${ }^{42}$ the margin of appreciation gives the Court the possibility of broadly interpreting what constitutes a "public interest" that can allow a limitation of the right of propriety. However, in Born's view, there was no provision in the text of the BIT that is equivalent to the text of Art. 1 Protocol 1 of the ECtHR. The BIT just set forth an obligation and an appropriate standard of review. As a result the Tribunal should focus simply on the text of the BIT. Such a text, of course, involves a certain degree of deference towards State sovereignty, but this "is not a substitute for reasoned analysis [...]: deference to sovereign measures is the starting point, but not the ending point, of evaluation of fair and equitable treatment claims. Rather, a sensitive and nuanced consideration of the nature of the governmental measure, the character and context of the governmental judgment, the relationship between the measure and its stated purpose, and the measure's impact on protected investments is necessary". ${ }^{43}$ In sum, what Born seems to suggest is to look at deference as a part of a broader proportionality analysis and not as the end of the story when assessing a potential violation of the FET standard. Indeed, the necessity of being deferent towards States' sovereignty is certainly an element to be taken into account when evaluating whether a state measure is proportional to its goals, but it is not the only element. Born's criticism to the award is therefore related to the fact that it seems only based on deference, without taking into account the other prongs of the proportionality analysis.

\section{The Relationship Between Indirect Expropriation and the Power to Regulate}

\subsection{The Customary Nature of the Police Powers Doctrine and Its Applicability in Investment Arbitration Cases}

41 See, in this regard, Born's Dissenting Opinion appended to the Philip Morris award, para. 181

42 See with regard to this article, PADELLETTI, Maria Luisa. Art. 1 Prot. 1. In: BARTOLE, Sergio; DE SENA, Pasquale; ZAGREBELSKY, Vladimiro. Commentario Breve alla Convenzione europea dei diritti dell'nomo. CEDAM, 2012. p. 791.

43 See Born's Dissenting Opinion, n. 40 above, para. 142. 
The decision in Philip Morris, in its part concerning the indirect expropriation claim, suggests that - in the cases where certain State measures which investors may consider to be a deprivation of property take place in the pursuance of public interests and provided that such measures are proportional to their goals - the State's measure cannot be considered tantamount to expropriation and compensation is not due. ${ }^{44}$ It is worth recalling here that, according to the arbitrators, such a result may be reached by means of recourse to the rule of systemic interpretation set forth by Art. 31(3)(c) VCLT.

However, while in this author's opinion the objective that the Tribunal wanted to achieve (i.e. deference towards Uruguay's sovereignty in matters of essential public interest) deserves praise, because it could improve the perception of legitimacy of investment arbitration both from the perspective of States and from the perspective of the public opinion, the legal path followed by the Arbitrators does not seem entirely convincing. The reason for this puzzlement regarding the Tribunal's legal reasoning stays in the fact that, in order to say that a government may substantially affect the value of a property by means of a general regulation without incurring a duty to compensate investors, an in-depth analysis on the customary nature of the police powers doctrine and on the ways in which it may derogate from treaty obligations is required. Such an analysis should have been made, first, from a historical perspective and, second, on the basis of a conflict of norms approach. We will try to carry out this task in the present Section, in order to understand whether the Philip Morris Tribunal's approach may find a legal justification.

From the historical point of view, it is undisputable that an afterthought concerning the goals and scope of

44 For an analysis of the concepts and differences between direct and indirect expropriation see KNAHR, Christina. Indirect Expropriation in Recent Investment Arbitration. Austrian Review of International and European Law, v. 12, p. 85, 2007; ISAKOFF, Peter. Defining the Scope of Indirect Expropriation for International Investments. Global Business Law Review, v. 3, p. 189, 2013; FORTIER, Yves; DRYMER, Stephen. Indirect Expropriation in the Law of International Investment: I Know It When I See It, or Caveat Investor. ICSID Review - FILJ, v. 19, p. 293, 2004; KUNOY, Bjørn. Developments in Indirect Expropriation Case Law in ICSID Transnational Arbitration. Journal of World Investment \& Trade, v. 6, p. 467, 2005; HEISKANEN, Veijo. The Doctrine of Indirect Expropriation in Light of the Practice of the Iran - United States Claims Tribunal. Journal of World Investment \& Trade, v. 8, p. 215, 2007; PUPOLIZIO, Ivan. The Right to an Unchanging World - Indirect Expropriation in International Investment Agreement and State Sovereignty. Vienna Journal of International Constitutional Law, v. 10, p. 143, 2016. investment treaty protections is taking place. In their early age investment treaties contained "broad protection for foreign investors, with little or no reference to the need to balance investor protections against public policy goals". ${ }^{45}$ Arbitrators looked at investment claims as ordinary commercial disputes. One of the consequences of this approach was the application of the "sole effects doctrine" to expropriation claims. According to this doctrine the mere fact that a deprivation of propriety (either direct or indirect) had taken place entitled investors to compensation, regardless of the State reasons behind the regulatory measures. ${ }^{46}$ Such a doctrine, originally grounded in the jurisprudence of the Iran-US Claims Tribunal, ${ }^{47}$ is perfectly explained in the Santa Elena award, where the Tribunal said that "expropriatory environmental measures - no matter how laudable and beneficial to society as a whole - are, in this respect, similar to any other expropriatory measures that a state may take in order to implement its policies: where property is expropriated, even for environmental purposes, whether domestic or international, the state's obligation

45 ROBERTS, Anthea, Clash of Paradigms: Actors and Analogies Shaping the Investment Treaty System, American Journal of International Law, v. 107, p. 76, 2013. This attitude extremely favourable to investors has been described as a reaction to the extremely unprotective regime regarding foreign investments which took place at the period of decolonization. Indeed, during that period, capital importing States accepted burdensome obligations towards foreign investors with the aim of attracting foreign capital. See SACERDOTI, Giorgio, The Proliferation of BITs: Conflicts of Treaties, Proceedings and Awards, in SAUVANT, Karl, et al. (eds.), Appeals Mechanism in International Investment Disputes, Oxford: Oxford University Press, p. 133, 2008. On the other hand, it could be said that capital importing States did not understood how burdensome the obligations they were assuming would have revealed to be. See, in this regard, the policy paper issued by the South African government in 2009, mentioned in MARKERT, n. 1 above, p. 146, footnote 5 , where it is said that "the impact of BITs on future policies [was] not critically evaluated. As a result the Executive entered into agreements that were heavily staked in favour of investors without the necessary safeguards to preserve flexibility in a number of policy areas."

46 See, also for the case law mentioned therein, MOSTAFA, Bem. The Sole Effects Doctrine, Police Powers and Indirect Expropriation under International Law. Australian International Law Journal, v. 15, p. 279, 2008; YANNACA-SMALL, n. 25 above, p. 14-16; see also DOLZER, n. 17 above, p. 79 TITI, Aikaterini. Refining the Expropriation Clause: What Role for Proportionality?. 2017. p. 1. Disponível em: <https://papers.ssrn.com/sol3/papers.cfm?abstract_ id $=2978530>$. p. 12 discussed about the sole effects as a doctrine which is "agnostic about the purpose of the host state measure and only examines the effect it has on the investor".

47 See Tippetts, Abbett, McCartby, Stratton v. TAMS-AFFA, IranUS Claims Tribunal, Decision, 22 June 1985, available at Iran-U.S. Claims Tribunal Report, v. 6, p. 219 , 1985; Starrett Housing Corp. v. Iran, Iran-U.S. Claims Tribunal Report, v. 16, p. 112, 1987. 
to pay compensation remains". ${ }^{48}$

Today, however, the situation has dramatically changed. This is probably related to the fact that developed countries such as USA, Canada and Australia have started to be involved in investment arbitration cases as respondents. ${ }^{49}$ These countries, who allegedly have a bigger bargaining power when negotiating BITs, originally accepted treaty wordings very favourable to investors, probably because they did not foresee that they could have become respondents in future investment arbitrations. This scenario, however, recently materialized. Hence, also from the side of these countries, there is a new emphasis on the necessity to duly take into account the States' sovereign functions in the evaluation of the legitimacy of regulatory measures ${ }^{50}$ enacted with the aim of protecting essential public services and/or protecting human rights. ${ }^{51} \mathrm{We}$ are thus facing "a return of the State" in international investment law. ${ }^{52}$

The power to regulate, traces of which can be found also in the practice of the Iran-US Claims Tribunal, ${ }^{53}$ emerged as a part of this trend. The doctrine's relevance

48 Compania del Desarrollo de Santa Elena, S.A. v. Costa Rica, ICSID Case No. ARB/96/1, Final Award, 17 February 2000, para. 72. Similarly see Pope and Talbot Inc. v. Canada, UNCITRAL, Interim Award, 26/06/2000, para. 102; Patrick Mitchell v. The Democratic Republic of Congo, ICSID Case No. ARB/99/7, Annulment Decision, 01/11/2996, para. 53.

49 REISMAN, W Michael. The Empire Strikes Back: The Struggle to Reshape ISDS. 2017. p. 12. Disponível em: < https://papers.ssrn. com/sol3/papers.cfm?abstract_id=2943514>; see also ROBERTS, n. 45 above, p. 78 .

50 See SCHREUER, Christoph; KRIEBAUM, Ursula. From Individual to Community Interest in International Investment Law. In: FASTENRATH, Ulrich et al. (Ed.). From Bilateralism to Community Interest. Essays in Honour of Judge Bruno Simma. Oxford University Press, 2011. p. 1079 (arguing that investment law is by no means exclusively governed by individual interests but is also receptive to community interest).

51 Essential public interests are those which are perceived as extremely important for the achievement of a public goals and are usually aimed at ensuring the protection of essential human rights. See, in this regard, RUBINI, Luca, L'impatto del GATS sulla regolazione nazionale dei servizi di interesse generale, Diritto del commercio internazionale, v. 21, p. 376, 2007.

52 ALVAREZ, Jose E. The Return of the State. Minnesota Journal of International Law, v. 20, p. 223, 2011.

53 SEDCO Inc. v. National Iranian Oil Co., Iran - United States Claims Tribunal, Decision, 27/03/1986, available at Iran-US Claims Tribunal Report, v. 9, p. 248. At 275 the Tribunal stated that it is "an accepted principle of international law that a State is not liable for economic injury which is a consequence of bona fide 'regulation' within the accepted police powers of the State". See in this regard, ALDRICH, George, What Constitutes a Compensable Taking of Property? The Decisions of the Iran United States Claims Tribunal. American Journal of International Law, v. 88, p. 609, 1994. in the reasoning of arbitral tribunals and in the text of modern investment treaties is today a matter of fact. ${ }^{54}$ Indeed, as already briefly mentioned, there are several decisions that have recognized the right to regulate as an essential attribute of States. Among those, it is worth recalling the reasoning of the Tribunal in Chemtura, a dispute regarding the ban enacted by Canada with regard to a dangerous pesticide called lindane, which negatively affected the Claimant's business. Arbitrators said that "[i] rrespective of the existence of a contractual deprivation, the Tribunal considers in any event that the measures challenged by the Claimant constituted a valid exercise of the Respondent's police powers [...]. The [State] took measures within its mandate, in a non-discriminatory manner, motivated by the awareness of the dangers presented by lindane for human health and environment". ${ }^{55}$ A very similar wording was used in Methanex, ${ }^{56}$ where the Tribunal again recognized the customary nature of the State police powers doctrine, Saluk $a^{57}$ and Marvin Feldman. ${ }^{58}$ In this last decision, the Tribunal expressly made reference to the impossibility for States to pay compensation in cases involving the exercise of police powers. It said that "governments must be free to act in the broader public interest through the protection of the environment, new or modified tax regimes, the granting or withdrawal of government subsidies, reductions or increases in tariff levels, imposition of zoning restrictions and the like. Reasonable

54 See WÄLDE, Thomas; KOLO, Abba. Environmental Regulation, Investment Protection and 'Regulatory Taking in International Law. The International and Comparative Law Quarterly, v. 50, p. 811, 2001; RATNER, Steven. Regulatory Takings in Institutional Context: Beyond the Fear of Fragmented International Law. American Journal of International Law, v. 102, p. 475, 2008; MARLLES, Justin. Public Purpose, Private Losses: Regulatory Expropriation and Environmental Regulation in International Investment Law. Journal of Transnational Law and Policy, v. 16, p. 275, 2006-2007.

55 Chemtura award, n. 4 above, paras. 265-266.

56 Methanex award, n. 4 above, Part. 4, Chapter D, Para 7, stating that "as a matter of general international law, a non-discriminatory regulation for a public purpose, which is enacted in accordance with due process and, which affects, inter alios, a foreign investor or investment is not deemed expropriatory and compensable unless specific commitments had been given by the regulating government to the then putative foreign investor contemplating investment that the government would refrain from such regulation".

57 See n. 27 above, para. 255, where it is said that "[i]t is now established in international law that States are not liable to pay compensation to a foreign investor when, in the normal exercise of their regulatory powers, they adopt in a non-discriminatory manner bona fide regulations that are aimed at the general welfare". See also paras. 260 and 262

58 See Marvin Feldman v. Mexico, ICSID Case No. ARB(AF)/99/1, Award, 16/12/2002, para. 103. 
governmental regulation of this type cannot be achieved if any business that is adversely affected may seek compensation" (emphasis added).

Provisions excluding the expropriatory nature (and therefore the descending necessity of compensation) of regulatory measures may also be found in recent investment treaties. It is worth mentioning, in this regard, Art. 3 of Annex 8-A of the CETA, which states that "except in the rare circumstances when the impact of a measure or series of measures is so severe in light of its purpose that it appears manifestly excessive, non-discriminatory measures of a Party that are designed and applied to protect legitimate public welfare objectives, such as health, safety and the environment do not constitute indirect expropriation". Another very significant provision pointing in this direction is set forth in Art. 23 of the Morocco - Nigeria BIT of 3 December 2016, entitled "Right to Regulate" and stating, in its first paragraph, that "the Host State has the right to take regulatory or other measures to ensure that development in its territory is consistent with the goals and principles of sustainable development, and with other legitimate social and economic policy objectives". Similar rules can be found in several other recently drafted treaties, including the 2012 BIT between Canada and China, ${ }^{59}$ the 2012 US Model BIT, ${ }^{60}$ the new Indian Model BIT of $2015,{ }^{61}$ among many others. ${ }^{62}$

Is the above sufficient to reach the same conclusion of the Philip Morris Tribunal, i.e. that the power to regulate is a customary international law rule? In order to say that the right to regulate is a rule of customary international law, it is necessary to first verify the existence of the two elements of custom, namely diuturnitas and opinio juris sive necessitatis. ${ }^{63}$ The former consists in the uniform repetition by the community of States of a certain conduct, while the latter corresponds to the

59 See Art. 33.

60 See Art. 12.

61 See the Indian Model Text for the Bilateral Investment Treaty, Art. 16 (General Exceptions). See in this regard HANESSIAN, Grand; DUGGAL, Kabir. The Final 2015 Indian Model BIT: Is This the Change the World Wishes to See?. ICSID Review - FILJ, v. 32 , p. 218,2017

62 See the meaningful analysis carried out by TITI, n. 7 above, p. 53 ; see also references contained in COLLINS, n. 1 above, pp. 579-580.

63 CONFORTI, Benedetto. Diritto Internazionale. 10. ed. Editoriale Scientifica, 2015. See also TREVES, Tullio. Customary International Law, Max Planck Enciclopedia of Public International Law. 2010. Disponível em: <www.mpepil.com>. perception (rectius, the conviction) of the necessity and of the binding nature of such a conduct. From a reading of the Philip Morris award, it seems that the mere reference to the 1961 Harvard Draft Convention, to the Third Restatement of the Foreign Relations Law of the United States of 1987, to the works of the OECD, to the wording of a limited number of investment treaties and to certain arbitral awards would be sufficient to prove the existence of a custom, but the Tribunal avoided any kind of discussion on the requirements of diuturnitas and opinio juris sive necessitatis, probably considering that their meeting was in re ipsa.

However, contrary to the Tribunal's approach, it is first of all to be noted that the presence of wordings recognizing the power to regulate in a number of BITs and other non-binding legal texts - as well as in the text of certain arbitral awards - is probably still insufficient to demonstrate that the requirement of diuturnitas has been met. Indeed, such BITs still constitute a very limited percentage of existing investment treaties, usually estimated as more than $3000 .{ }^{64}$

In light of the above, it seems that there are still few tangible elements which may prove helpful in demonstrating that the community of States considers the police powers doctrine as necessary and binding. It is not by chance, indeed, that still a limited number of Tribunals have recognized and applied the doctrine ${ }^{65}$ and that there is still disagreement among authors on the necessity of awarding compensation to investors in cases of State measures that, on the one hand, are enacted with the aim of protecting public interests, but, on the other hand, actually deprive investors' properties of their va-

64 It is also worth noting that - among the newest investment treaties - the recent Brazilians Cooperation and Investment Facilitation Agreements are silent on the matter and this could be seen as a confirmation of the fact that not all governments feel it necessary to put a provision on the power to regulate in their recent draft of investment treaties. See, e.g., the 2015 treaties signed by Brazil and Angola and Brazil and Mozambique. For comments to Brazilian investment treaties see MONEBHURRUN, Nitish. Novelty in International Investment Law: The Brazilian Agreement on Cooperation and Facilitation of Investments as Different International Investment Agreement Model. Journal of International Dispute Settlement, v. 8, p. 79, 2017.

65 See TITI, n. 7 above, p. 289, stating that "the wide cast of existing interpretations does not permit the deduction that tribunals accommodate host state policy space". See also ACCONCI, n. 2 above, p. 179, who adds that the application of the doctrine "has not happened in a systematic way as only a few arbitral tribunals have allowed this kind of derogation". 
lue. ${ }^{66}$ Scholarly articles dealing with this question look at the power to regulate as something that is correct and desirable but still to be achieved. ${ }^{67}$

It can be said that there is an emerging trend towards the affirmation of the police powers doctrine in international investment law, within which the Pbilip Morris award is perfectly integrated. Whether this trend will convert into a customary rule, however, it is too early to say. In this regard, therefore, the conclusion reached in the Philip Morris award seems rushed. Indeed, the traditional wording of BITs (including Art. 5 of the Swiss-Uruguayan BIT which was applied in Philip Morris) concerning expropriation, both direct and indirect, is usually very clear in stating that compensation is due in all the cases where an expropriation takes place. ${ }^{68}$ In this regard, it is to be noted that - in the presence of this kind of wording in expropriation clauses - States are not free to disregard an obligation that they previously freely assumed. A derogation ${ }^{69}$ to the obligation to pay compensation in cases of expropriation is not allowed unless in the presence of another rule of international law (either conventional or customary) providing otherwise. ${ }^{70}$

It comes as a direct consequence of the above that, contrary to the approach in Philip Morris, even if one ad-

66 DE LUCA, n. 17 above, p. 71 uphold the idea that compensation is always due, even in cases of regulatory takings; similarly, see LEVESQUE, Céline. The inclusion of GATT Article XX exceptions in IIAs: a potentially risky policy. In: ECHANDI, Roberto; SAUVE', Pierre. Prospects in International Investment Law and Policy. Cambridge University Press, 2013. p. 367-368. A different approach, however, seems to be sustained by other authors. Inter alia, see TESAURO, Giuseppe. Naz̧ionalizzazioni e diritto Internazionale. Edizioni Scientifiche Italiane, 1976. p. 165-166, stating that customary international law does not impose compensation in cases of general, non-discriminatory regulatory takings aimed at safeguarding public interest. Also FRIGO, Manlio. Le limitazioni dei diritti dei privati nel diritto Internazionale. Milan: Giuffrè Editore, 2000. p. 120.

67 TITI, n. 7 above, p. 298-303; DOLZER, Rudolf; BLOCH, Felix. Indirect Expropriation: Conceptual Realignments?. International Law FORUM du droit international, v. 5, p. 163-165, 2003.

68 This is, indeed, the thesis sustained by DE LUCA, n. 17 above, p. 58 The question of the amount of compensation to be paid by host States in cases of expropriation has been analysed in-depth in a recent article by RATNER, Steven R. Compensation for Expropriation in a World of Investment Treaties: Beyond the Lawful/ Unlawful Distinction. 2017. Disponível em: <https://ssrn.com/ abstract $=2954146>$.

69 PAULSSON, Jan. The Power of States to Make Meaningful Promises to Foreigners. Journal of International Dispute Settlement, v. 1, p. 341, 2010.

70 VILLIGER, Mark. Customary International Law and Treaties. The Hague: Martinus Nijhoff Publishers, 1985. p. 215. mits that a customary rule on the right to regulate exists (something that is here denied), such a rule is not to be applied in investment arbitration by means of a systemic integration according to Art. 31(3)(c) VCLT. Indeed, for the reasons outlined above, in the cases where BITs expressly set forth an obligation of compensation, the possibility to deny compensation may not be affirmed by way of systemic interpretation (and, instead, a conflict of norms approach is required). As explained by Simma and Kill, "[w]hen interpreting a treaty, the adjudicator draws out the specific norms memorialized in a treaty; when modifying a treaty, the adjudicator replaces these treaty norms with others". ${ }^{71}$ Art. 31(3)(c) requires interpreters to take into account rules of international law applicable between the parties; it does not, however, authorize them to arbitrarily substitute the text of a treaty with another rule of international law. Art. 31(3)(c) is "a tool of interpretation not explicitly vested with the power to modify". ${ }^{72}$ In conclusion, systemic interpretation does not seem the proper legal tool to introduce in investment arbitration a concept, such as the right to regulate, which requires a clear normative basis in order to be applied and to justify the absence of compensation in presence of measures which substantially affect the value of investors' property.

\subsection{Proportionality as a Possible Tool to Take into Account State Interests in Indirect Expropriation Cases}

71 SIMMA, Bruno; KILL, Theodore. Harmonizing Investment Protection and International Human Rights: First Steps Towards a Methodology. In: BINDER, Christina (et al.). International Investment Law for the 21st Century: Essays in Honour of Christoph Schreuer. Oxford University Press, 2009. p. 692.

72 SIMMA, Bruno; KILL, Theodore. Harmonizing Investment Protection and International Human Rights: First Steps Towards a Methodology. In: BINDER, Christina (et al.). International Investment Law for the 21st Century: Essays in Honour of Christoph Schreuer. Oxford University Press, 2009. p. 694. Similarly, see GRECO, Roberta. The Impact of the Human Right to Water on Investment Disputes. Rivista di Diritto Internazionale, v. 98, p. 484, 2015. The usefulness of art. 31(3)(c) has been defined as overestimated by PUMA, n. 3 above, p. 221. With regard to Art. 31 VCLT in investment arbitration see, in general terms, ASCENSIO, Hervé. Article 31 of the Vienna Convention on the Law of Treaties and International Investment Law. ICSID Review - FILJ, v. 31, p. 366, 2016; Art. 31(3) (c) is analysed in-depth by MCLACHLAN, Campbell. The Principle of Systemic Integration and Art. 31(3)(c) of the Vienna Convention. International and Comparative Law Quarterly, v. 54, p. 279, 2005; FOCARELLI, Carlo. Trattato di diritto Internazionale. Torino: UTET, 2015. p. 407. 
The above considerations, however, cannot lead us to exclude the possibility that State interests are duly taken into account by arbitrators when evaluating the existence of an indirect expropriation. As we have seen above, it seems that if the sovereign prerogatives of States are not duly taken into account in investment arbitration, this circumstance would lead the entire dispute settlement mechanism to lose its legitimacy. ${ }^{73}$ The Philip Morris award shows that arbitrators were perfectly conscious of this risk and this seems to have been the implied reason behind their very favourable approach toward the power to regulate doctrine. This effort, as well as the final conclusions reached by the Tribunal, as already said, deserves praise. It appears therefore necessary to try to find a different legal justification aimed at reaching the same conclusion.

A possible solution to this problem has been identified in the application of the principle of proportionality, ${ }^{74}$ which is only briefly mentioned in the part of the Philip Morris award dealing with the indirect expropriation claim. ${ }^{75}$ As previously outlined, following

73 See BROWER, Charles H. II, Obstacles and Pathways to Consideration of the Public Interest in Investment Treaty Disputes. Yearbook of International Investment Law and Policy, p. 347, 2008-2009.

74 The recourse to the principle of proportionality to resolve this kind of conflicts has been already proposed by SCHILL, Stephan; KINGSBURY, Benedict. Public Law Concepts to Balance Investors' Rights with State Regulatory Actions In the Public Interest: The Concept of Proportionality, in SCHILL, Stephan (Ed.), International Investment Law and Comparative Public Law. Oxford: Oxford University Press, 2010. p. 75; PELLET, Alain. Police Powers or the State's Right to Regulate. In: KINNEAR, Meg et al. (Ed.). Building International Investment Law: The First 50 Years of ICSID, Kluwer Law International. 2015. p. 458; STONE SWEET, Alex, DELLA CANANEA, Giacinto. Proportionality, General Principles of Law, and Investor-State Arbitration: A Response to Jose Alvarez. NYU Journal of International Law and Politics, v. 46, p. 914, 2014; similarly see HENCKELS, Caroline. Indirect Expropriation and the Right to Regulate: Revisiting Proportionality Analysis and the Standard of Review in Investor-State Arbitration. Journal of International Economic Law, v. 15, p. 223, 2012. For an analysis of proportionality in international investment law see HAN, Xiuli. The Application of the Principle of Proportionality in Tecmed v. Mexico. Chinese Journal of International Law, v. 6, p. 635, 2007. An approach based on the concept of "reasonableness", which per se involves also a proportionality analysis has been sometimes endorsed also by the ICJ. See, in this regard, RUSSO, Deborah. Sull'uso della ragionevolezza da parte della Corte internazionale di giustizia nel controllo sull'esercizio dei poteri discrezionali degli stati. Rivista di diritto internazionale, v. 98, p. 487,2015 . A balancing is, however, required in all cases where there is a contrast between two valid and existing rights. See, in this regard, PINO, Giorgio. Conflitto e bilanciamento tra diritti fondamentali: Una mappa dei problemi. Etica e politica, v. 8, p. 1, 2006.

75 See Philip Morris award, n. 10 above, para. 305, where the proportionality of the State measures is considered as one of the re- several authoritative scholars, it seems possible to identify the principle of proportionality as a general principle of international law ${ }^{76}$ which has "permutations according to the specific area in which it operates". ${ }^{77}$ Being a primary source of international law, such a principle is potentially able to interact on a paritarian level with treaty provisions on expropriation (which, of course, are a primary source of international law too) and, as a consequence, to induce a certain reading of such clauses .

In the context of international investment law, proportionality imposes a balancing of interests aimed at understanding whether the sacrifice requested to investors is commensurate with the relevance of the ob-

quirements for the application for the police powers doctrine.

76 See, also for reference to several other authorities pointing in the same direction, PALOMBINO, n. 9 above, p. 152 ; similarly see BEHARRY, Christina; KURITZKY, Melinda. Going Green: Managing the Environment Through International Investment Arbitration. American University International Law Review, v. 30, p. 426, 2015. This is not the place to carry out a meaningful analysis of proportionality in international law. However, suffice it to say that Palombino's approach seems very convincing in light of the fact that the balancing exercise based (explicitly or impliedly) on the threepronged test of proportionality, as the same Author demonstrates, appears present in the vast majority of the domestic system of law, in EU law and in international law. A meaningful analysis of the legal status of proportionality has been recently carried out by TITI, n. 46 above, p. 3 , who explained that proportionality has been seen in scholarship either as a general principle of law (something that seems questionable to that author due to the facts that, as she explains at 18 , she sees proportionality as absent from some domestic legal systems and that at the international level proportionality does not seem to her as universally accepted) or as an element of material law, applicable only if incorporated in a particular set of rules. Other authors, however, talked about different legal basis for the principle. See, inter alia, COHEN, Abby; SHANY, Yuval. A Development of Modest Proportions. The Application of the Principle of Proportionality in the Targeted Killing Case. Journal of International Criminal Justice, v. 5, p. 310, 2007, who talked about a customary rule; and CANNIZZARO, n. 9 above, p. 429 , who excludes the existence of a general rule of international law and discusses proportionality as a balancing technique that is functional to the application of other rules of international law; BUCHELER, n. 9 above, p. 28, talks of proportionality as a general principle of law recognized by civilized nations in the sense of Art. 38(1)(c) of the Statute of the International Court of Justice. Some authors criticize proportionality because it allegedly involves a law-making function by judges that should be avoided. See, inter alia, COTTIER, Thomas et al. The Principle of Proportionality in International Law. NCCR Trade Working Paper No. 2012/38, 2012. p. 19. Finally, a strong critic to proportionality has been made by SORNARAHAH, Mutucumaraswamy. Resistance and Change in the International Law of Foreign Investment. Cambridge: Cambridge University Press, 2015. p. 365.

77 See PALOMBINO, n. 9 above, p. 152; CRAWFORD, Emily. Proportionality. In: WOLFRUM, Rudiger (Ed.). Max Planck Encyclopaedia of Public International Law. 2013. Online version. 
jectives of the host State. Such a balancing exercise is to be carried out on the basis of the satisfaction of a three-pronged test: first, the State measure shall be considered suitable for reaching its goals (suitability); second, the measure shall be necessary, i.e. less restrictive of investors' interests (necessity); and, finally, it shall be proportional stricto sensu, i.e. - in concreto - it shall not have too restrictive effects on investors' rights in comparison with the State interests that it seeks to protect. ${ }^{78}$ As a matter of principle, this means that if the sacrifice imposed on the investor is disproportionate to the State's objectives, compensation is due. Instead, if there is a reasonable balance between the State's goals and the sacrifices required from the investors (i.e. if the objectives of the State's measures are considered by the adjudicating authority so important as to justify a certain degree of prejudice to investors' rights), compensation is not due.

According to existing authorities, there are two ways in which the principle of proportionality may be applied in relation to indirect expropriation. The first of them has been drawn in the well-known Tecmed award, ${ }^{79}$ according to which " $[\mathrm{a}]$ fter establishing that regulatory actions and measures will not be initially excluded from the definition of expropriatory acts, in addition to the negative financial impact of such actions or measures, the Arbitral Tribunal will consider, in order to determine if they are to be characterized as expropriatory, whether such actions or measures are proportional to the public interest presumably protected thereby and to the protection legally granted to investments, taking into account that the significance of such an impact has a key role upon deciding the proportionality [...]. There must be a reasonable relationship of proportionality between the charge or weight imposed on the foreign investor and the aim sought to be realized by any expropriatory measure". This award seems to imply that, as stated above, if the State's general (and non-discriminatory) measures are not disproportionate, they could be classified as non-expropriatory and, hence, compensation is not warranted.

The second way in which the proportionality principle could be applied in the present context has been proposed by Ursula Kriebaum. ${ }^{80}$ This author starts

78 See TITI, n. 46 above, p. 3.

79 Tecmed award, n. 26 above, para. 122.

80 KRIEBAUM, Ursula. Regulatory Takings: Balancing the Interests of the Investor and the State. Journal of World Investment \& from the assumption that the approach endorsed in the Tecmed award would lead us to an "all or nothing paradigm", in virtue of which an expropriation takes place if the State measure is disproportionate (and, therefore, compensation is due) and vice-versa. However, in Kriebaum's opinion, there are several cases which might be defined as borderline and in which - while a full compensation is inappropriate - the exclusion of any reimbursement for the investor is too burdensome a grievance for him. Hence, Kriebaum proposes the application of the proportionality test not to the existence of an indirect expropriation but to the amount of compensation. In Kriebaum's view, four elements ought to be taken into account in this evaluation. ${ }^{81}$ First one should look at the necessity and suitability of the measure to reach the public purpose. Second, the genuineness of the public purpose should be evaluated. Third, arbitrators should take into account the legitimate expectations of the investor generated by inducements of the host State. Finally, adjudicators should verify whether a special public interest to pay less than full compensation exists. After having carried out the above analysis, Tribunals should evaluate the amount of compensation. In Kriebaum's words: “[ $\mathrm{t}]$ he maximum would be full compensation. Conversely, if an expropriation is the least invasive suitable means to achieve the public purpose, compensation will be lower depending on how urgent and genuine the public interest to expropriate is. In addition, an exceptional public interest to expropriate with less than full compensation will also affect the amount of compensation". 82

With regard to the above approaches, it should be noted that Prof. Kriebaum's view - even if theoretically stimulating - seems to be difficult to apply in practice. In the absence of objective parameters, arbitrators would decide the amount of compensation to be paid on the basis of a merely subjective perception of the case at hand. Compensation, which by definition consists in a certain amount of money to be anchored to the violation of specific legal parameters, would turn out to be determined by an equitable decision of arbitrators with the risk of undermining the acceptability of

Trade, v. 8, p. 717, 2007.

81 KRIEBAUM, Ursula. Regulatory Takings: Balancing the Interests of the Investor and the State. Journal of World Investment \& Trade, v. 8, p. 732, 2007.

82 KRIEBAUM, Ursula. Regulatory Takings: Balancing the Interests of the Investor and the State. Journal of World Investment \& Trade, v. 8, p. 743, 2007. 
the resulting award. A proportionality analysis concerning the amount of compensation has been sometimes carried out by the ECtHR, which in some cases justified a graduation of the amount to be compensated on the basis of the circumstances of the case at hand.$^{83} \mathrm{In}$ this regard, it is to be noted that, as reported by various scholars, a uniform criterion emerging from the Court's jurisprudence did not emerge, and that is why the same ECtHR is applying a more rigid approach (i.e. mainly anchored to the full economic value of the expropriated asset) in the evaluation of the amount of compensation to be paid. ${ }^{84}$ It is not surprising, therefore, that such an approach did not find application in the practice of investment tribunals.

The Tecmed Tribunal's approach, instead, seems to be the most suitable for indirect expropriation cases. ${ }^{85}$ Such an approach has found approval also in other decisions, such as LG\&E, where the Tribunal stated that "[w]ith respect to the power of the State to adopt its policies, it can generally be said that the State has the right to adopt measures having a social or general welfare purpose. In such a case, the measure must be accepted without any imposition of liability, except in cases where the State's action is obviously disproportionate to the need being addressed". ${ }^{86}$ A similar position has been taken in Azurix ${ }^{87}$ and recently also the German Constitutional Court in Vattenfall seems to have affirmed that disproportionate expropriations need to be compensated. ${ }^{88}$ This means that, on the basis of the aforementioned three-step structure of proportionality, and starting from the necessary assumption that States supposedly

83 See, inter alia, ECtHR Kozacioglu v. Turquie, No. 2334/03, 19/02/2009, para. 64. See also the Case of the Holy Monastries v. Greece, No. 13092/87 and 13984/88, 09/12/1994, paras. $70-71$ (in which the Court has also recognized the possibility of expropriation without compensation in exceptional circumstances).

84 See, inter alia and also for other references, PADELLETTI, n. 42 above, pp. 800-801; ECtHR, Grand Chamber, Scordino v. Italie, N. 36813/97, 21/03/2006, para. 96.

85 The diffusion of this approach, also known as "all or nothing approach" is recognized also by TITI, n. 46 above, p. 14 .

86 LG\&E Energy Corp., LG\&E Capital Corp., LG\&E International Inc. v. The Argentine Republic, ICSID Case No. ARB/02/1, Decision on Liability, 03/10/2006, para. 195.

87 Azurix Corp. v. The Argentine Republic, ICSID Case No. ARB/01/12, Award, 14/07/2006, paras. 311-312 and 322.

88 See Vattenfall v. Germany, Judgment of the German Constitutional Court, 06/12/2016. Available at: http://www.italaw.com/ sites/default/files/case-documents/italaw7894.pdf. For a comment see LAVRANOS, Nikos. The German Constitutional Court in the Vattenfall Case: Lessons for the ECT Vattenfall Tribunal. 2016. Available at: www.kluwerarbitrationblog.com. operate with the sole goal of safeguarding public interest, tribunals should be able to evaluate whether an investor suffered a too onerous prejudice ${ }^{89}$ with respect to the host State's goals. If investors have suffered an unproportionate damage, the regulatory measures shall be classified as expropriatory (and vice-versa). This kind of approach could have been also applied by the Philip Morris Tribunal in order to obtain an identical result to the one that it gained by applying the power to regulate doctrine and, in this author's opinion, this would have rendered the decision more legitimate. Indeed, it is arguable that the sacrifice imposed to Philip Morris was proportionate to the objectives of the measures enacted by Uruguay, i.e. the protection of the health of the population, and that, therefore, the measures were not expropriatory and no compensation was due to the Claimants. Indeed, Uruguay was, in its quality of the ultimate guarantor of the health of its population, fully entitled to enact measures that - in the name of the protection of the right to health - generated a certain degree of prejudice to tobacco producers. Such a prejudice, as recognized by the same arbitral Tribunal, could have been expected by investors acting in a sensitive area such as the sale of tobacco products and is therefore not unreasonable in light of the importance of the goals pursued by the State.

\section{The State Margin of Appreciation Regarding Violations of the Fair and Equitable Treatment Standard: A Different Name for the Proportionality Analysis?}

The police powers doctrine, examined in the previous Section, is not the only legal tool employed in the Philip Morris award in order to show deference towards Uruguay's sovereignty.

Indeed, in the second relevant part of the Philip Morris award, which concerns the possible violation of the fair and equitable treatment standard ${ }^{90}$ (in par-

89 See, also with regard to the degree of prejudice that investors might sustain, PALOMBINO, n. 9 above, p. 169-171.

90 The content and the legal status of the fair and equitable treatment standard is subject to huge debate in international investment law scholarship. See, inter alia, PALOMBINO, n. 9 above, p. 1., TUDOR. The Fair and Equitable Treatment Standard in International Investment Law. Oxford: Oxford University Press, 2008. p. 1; KLÄGER, Roland. Fair and Equitable Treatment' in International Investment Law. 
ticular with regard to the alleged arbitrariness of the measures and the investors' legitimate expectations that the legal framework existing in Uruguay regulating the commerce of cigarettes would not have changed), the majority of the Philip Morris Tribunal considered that Uruguay enjoyed a margin of appreciation in determining whether the single presentation requirement and the $80 / 80$ regulation were necessary for safeguarding public health. In the majority's view, the mere existence of this margin of appreciation is sufficient to render licit Uruguay's choices and conducts. For this reason, the majority considered it unnecessary to evaluate whether the measures were actually proportional with respect to their goal: it was sufficient that the host State considered that they were so. In this regard, as per the recourse to the police powers doctrine, the majority's decision on the FET claim, based on the recourse to the concept of margin of appreciation, appears to be driven by the same rationale which inspired the expropriation decision: being deferent towards Uruguayan sovereignty.

However, as already said with regard to the power to regulate, it is the opinion of the present author that while the deferential approach assumed by the Tribunal with regard to Uruguayan policy choices is admirable, the legal arguments employed by the arbitrators are controversial. In this Section, therefore, we will try to demonstrate that recourse to the margin of appreciation doctrine as developed in the ECtHR is probably inappropriate in the context of arbitrations arising from the violation of BIT standards. Such a recourse is, moreover, arguably useless, due to the fact that - as for the abovementioned expropriation claim - the goal of being deferent towards State policy choices may be equally reached by applying the principle of proportionality, the applicability of which in investment disputes is undisputed.

In order to assess the decision of the Philip Morris Tribunal on the fair and equitable treatment violation, we will therefore need to make a careful analysis on the margin of appreciation doctrine and on the ways in which it has been developed by the ECtHR and applied in different context.

In this Section we try to demonstrate that the thesis supporting the applicability of the margin of apprecia-

Cambridge: Cambridge University Press, 2011. p. 1; PAPARINSKIS, Martins. The International Minimum Standard and Fair and Equitable Treatmen. Oxford: Oxford University Press, 2013. p. 1. tion in investment arbitration probably refers to such a doctrine in an a-technical way, i.e. as a mere balancing technique involving a certain degree of deference towards State sovereignty, and not as it has been technically developed by the ECtHR. We will therefore give evidence of the circumstance that, in the investment arbitration context, the concept seems to turn out to be equal to the proportionality analysis which already takes place in the evaluation of FET violations and which already involves a deferential approach towards States' policy choices. As a consequence, the reference to the label "margin of appreciation" in international investment seems to be misleading.

\subsection{The Meaning(s) of the Margin of Appreciation Doctrine}

Notwithstanding the fact that the Tribunal based its decision on the alleged FET violation on the application of this doctrine, there is no definition of the margin of appreciation in the Philip Morris award. Indeed, defining the margin of appreciation doctrine is not an easy task. While the ECtHR case law and the related literature are rich in references to this concept, very few of these sources have attempted to offer a definition of it. The following survey of the existing authorities, however, seems to suggest that reference to the margin of appreciation has not taken place in one way only.

As it is noted in Gary Born's dissenting opinion, ${ }^{91}$ whoever has referred to the margin of appreciation in a rigorous way states that it consists in the recognition of a certain degree of discretion to ECtHR Contracting Parties by the ECtHR when evaluating the legitimacy of limitations to conventional rights imposed by States for reasons of public interest. ${ }^{92}$ This doctrine has been

91 Para. 181 In particular, at para. 183, with regard to Art. 1 of Protocol 1 of the ECHR, Mr. Born explains that such a rule "has been interpreted by the ECtHR to afford a very wide margin of appreciation to governmental authorities with respect to what constitutes 'public interest'. Among other things, the ECtHR has held that 'it should respect the legislature's judgment as to what is in the public interest unless that judgment is manifestly without reasonable foundation'. This interpretation of the Convention and its Protocols is supported by the traveaux preparatoires of the Convention, which indicate that the drafters intended to incorporate a 'very wide' margin of appreciation". The Dissenting Arbitrator, in this statement, referred to James and others $v$. United Kingdom, ECtHR, Series A No. 98, 21 February 1986, para. 46. It is possible to refer, in this regard, also to Broniovski v. Poland, ECtHR, Application No. 31443/96, Judgment, 22 June 2005, para. 149.

92 See, inter alia, YOUROW, Howard Charles. The Margin of 
applied by the ECtHR in well-defined circumstances, i.e. where the limiting measure is enshrined in a law, where it is necessary to realize a certain scope and where it is proportionate to its goal. ${ }^{93}$ Moreover, in order to grant a margin of appreciation to Contracting Parties, the Court requires that Contracting States do not have consistent views on the content of a certain right and the level of protection that States shall grant in relation to it. The different ways in which States conceive the same right justify different levels of interference with the enjoyment of such a right by people. ${ }^{94}$ If interpreted in this way, the margin of appreciation reveals itself to be a direct consequence of the principle of subsidiarity, one of the cornerstones of the ECHR system, according to which the ECtHR shall be deferential towards State authorities, which are better suited to regulate matters of public interest within their territory. As it has been explained by Prof. Samantha Besson, "States have the primary responsibility to secure human rights under jurisdiction; and international human rights institutions have a complementary review power in cases where international minimal human rights standards are not protected effectively domestically". ${ }^{5}$ The margin of ap-

Appreciation Doctrine in the Dynamics of European Rights Jurisprudence. Connecticut Journal of International Law, v. 3, p. 118, 2011, who defined the doctrine as the "breadth of deference" which the ECtHR gives to domestic decision-makers. See also the references contained in footnote 94 below.

93 There are plenty of examples in which the margin of appreciation doctrine has been used by the ECtHR. One of them concerns the possibility to limit the right to wear the islamic veil. In this regard see NIGRO, Raffaella. The Margin of Appreciation Doctrine and the Case-Law of the European Court of Human Rights on the Islamic Veil. Human Rights Review, v. 11, p. 531, 2010. Other cases concerns, e.g., the possibility to display crucifixes in public places, on which see the decision of the European Court of Human Rights, Grand Chamber, Lautsi and Others v. Italy, Application No. 30814/06, Judgment of 18 March 2011.

94 See, inter alia, PALOMBINO, n. 8 above, pp. 137-138. For the history and development of the margin of appreciation see MACDONALD, Ronald St. John. The Margin of Appreciation in the Jurisprudence of the European Court of Human Rights, in International Law at the Times of Its Codification: Essays in Honour of Roberto Ago. Giuffré, 1987. p. 187; BJORGE, Eirik. Been There, Done That: The Margin of Appreciation and International Law. Cambridge Journal of International and Comparative Law, v. 4, p. 181, 2015. In order to understand how the Court has applied the doctrine, see, inter alia, STAIANO, Fulvia. (In)Comparable Situations: Same-Sex Couples' Right to Marriage in European Case Law. 2017. p. 1. Disponível em: < diwww. federalismi.it>.

95 BESSON, Samantha. Subsidiarity in International Human Rights Law - What is Subsidiarity about Human Rights. The American Journal of Jurisprudence, v. 61, p. 69, 2016. See, in this regard, also NIGRO, Raffaella. Il margine di apprezzamento e la giurisprudenza della Corte europea dei diritti umani sul velo islâmico. Diritti umani preciation, therefore, "address[es] the limits or intensity of the review of the European Court of Human Rights in view of its status as an international tribunal". ${ }^{96}$ This conception of the margin of appreciation has been defined as "structural" and we could also describe it as "technical", in light of the fact that it is based on the rationale behind the development of the doctrine by the ECtHR.

However, as it has been noted by Prof. George Letsas, this is not the only meaning that has been given to the margin of appreciation..$^{8}$ According to the "substantive" conception of the doctrine, it "address[es] the relationship between individual freedoms and collective goals". ${ }^{99}$ When applying this conception of the doctrine, the Court recognizes a violation of a right, but allows it in light of the necessity to protect public interests. This understanding of the doctrine requires "a fair balance between individual rights and collective standards"100 and the most important step in its application consists in the evaluation of the proportionality of the measure. ${ }^{101}$ In Letsas's words “[t] he principle of proportiona-

e diritto internazionale, v. 2, p. 71, 2008. The margin of appreciation has been therefore correctly related to the concept of public policy in private international law; see SALERNO, Francesco. Il vincolo al rispetto dei diritti dell'uomo nel sistema delle fonti del diritto internazionale privato. Diritti umani e diritto internazionale, v. 8, p. 556, 2014. It is worth noting that this is not the only possible meaning of the subsidiarity principle, which has also a so-called "horizontal function" (opposed to the one we discuss in the present article, named "vertical subsidiarity"), aimed at regulating States' intervention in relation (and in substitution) of private parties' initiative. See, in this regard, BOCCHINI, Francesco. Contributo allo studio del diritto sussidiario. Rome: Aracne Editrice, 2012. p. 1.

96 LETSAS, George. Two Concepts of the Margin of Appreciation”. Oxford Journal of Legal Studies, v. 26, p. 706, 2006.

97 LETSAS, George. Two Concepts of the Margin of Appreciation". Oxford Journal of Legal Studies, v. 26, p. 706, 2006.

98 See also EL BOUDOUHI, Saïda. A comparative approach of the national margin of appreciation doctrine before the ECtHR, investment tribunals and WTO dispute settlement bodies. EUI Working Papers RSCAS 2015/27, 2015. p. 1. Similarly to Letsas, this Author recognize that the margin of appreciation can be understood "as a concept" referring to the "idea of leeway, discretion or space for manoeuvre that is granted by the normative structure of the law" or "as a doctrine" or "stricto sensu", i.e. as the ECtHR has technically developed it.

99 EL BOUDOUHI, Saïda. A comparative approach of the national margin of appreciation doctrine before the ECtHR, investment tribunals and WTO dispute settlement bodies. EUI Working Papers RSCAS 2015/27, 2015. p. 706.

100 EL BOUDOUHI, Saïda. A comparative approach of the national margin of appreciation doctrine before the ECtHR, investment tribunals and WTO dispute settlement bodies. EUI Working Papers RSCAS 2015/27, 2015. p. 711.

101 For a similar approach it is possible to mention BURKE- 
lity is by far the most important and most demanding criterion for whether the limitation of a right was permissible under the Convention. If the interference is found to be proportionate or 'necessary in a democratic society' the Convention right has not been violated". ${ }^{102}$ This understanding of the margin of appreciation doctrine could also be defined, in this author's opinion, as "a-technical", because - on the one hand - it is not anchored to strict requirements as it happens for the technical conception of the doctrine, and - on the other hand - it essentially seems to be an application of the autonomous principle of proportionality. ${ }^{103}$

\subsection{The Applicability of the Two Meanings of Margin of Appreciation in Investment Arbitration}

It is the present author's opinion that, as stated by Mr. Born's Dissenting Opinion in Philip Morris, ${ }^{104}$ the technical (or structural) conception of the margin of appreciation is completely unsuitable for the investment arbitration context with particular regard to the evaluation of FET violations. ${ }^{105}$ The reasons for this opinion are easy to elucidate.

The ECHR is a multilateral convention aimed at en-

WHITE, William; VON STADEN, Andreas. Private Litigation in a Public Law Sphere: The Standard of Review in Investor-State Arbitration. Yale Journal of International Law, v. 35, p. 307-308, 2010, who said that "practice suggests a relationship between the margin of appreciation and proportionality that we found both compelling and jurisprudentially useful. In practice, the Court uses the margin of appreciation to inform its proportionality analysis. In other words, when the Court grants a wide margin of appreciation to states in a given issue area, it then transforms that wide margin into a greater degree of deference to the national government in the proportionality balancing process which follows. A wide margin results in a less stringent proportionality test. A narrow margin leads to stricter review in the proportionality test".

102 LETSAS, George. Two Concepts of the Margin of Appreciation". Oxford Journal of Legal Studies, v. 26, p. 711, 2006.

103 Instead, the difference between the "technical" margin of appreciation and proportionality is clearly explained in DONATI, Filippo; MILAZZO, Pietro. La dottrina del margine di apprezzamento nella giurisprudenza della Corte europea dei diritti dell'uomo. In: FALZEA, Paolo; SPADARO, Antonino; VENTURA, Luigi. (Ed.). La Corte costituzionale e le corti d'Europa. Giappichelli, 2003. p. 110-111.

104 See para. 184.

105 The difficult applicability of the margin of appreciation has been analysed also with regard to the International Court of Justice. See RAGNI, Chiara. Standard of Review and the Margin of Appreciation Before the International Court of Justice. In: GRUSZCZYNSKI, Lukasz; WERNER, Wouter. Deference in International Courts and Tribunals. Oxford: Oxford University Press, 2014. p. 319. suring the protection of human rights in 47 States where, as obvious, there are substantial cultural differences in the perception of such rights. This, in turn, determines very different understandings of the reasons for which the rights protected by the Convention could be limited. It suffices here to mention questions such as the possibility to wear the Islamic veil in relation to the freedom of religion protected by Art. 9 of the ECHR. Each State has - based on its own policy choices - a different understanding of the ways in which such a right can be limited. ${ }^{106}$ The ECtHR, therefore, has been almost obliged in recognizing, through the margin of appreciation doctrine, a degree of flexibility in the application of conventional rights with respect to which uniformity among States is very difficult to be found. This approach finds support also in the consideration that, according to the above-mentioned principle of subsidiarity, the Court is to be considered in a worse situation (with respect to State authorities) in making evaluations involving substantial domestic policy considerations. ${ }^{107}$ Finally, it is to be noted that the rights of the ECHR in relation to which the application of the margin of appreciation has been recognized (i.e. Art. 8, 9, 10,11 and 15) all present a similar structure: the first paragraph draws the protected right and the second explains the conditions in presence of which a State may limit the enjoyment of such a right.

Contrariwise, BITs are bilateral treaties for the promotion and protection of investments made by nationals of one of the Contracting Parties in the other Contracting Party. Bilateral investment treaties involve certain limitations to State sovereignty that have been spontaneously accepted by States with the aim of attracting foreign capitals. They are not even comparable to a bill of rights such as the ECHR. Furthermore, considering that they do not involve rights in relation to which there are different cultural perceptions among States, they do not involve problems such as the lack of uniformity in the application of human rights. BITs do

106 See NIGRO, n. 95 above, p. 82.

107 For a meaningful discussion of the conditions behind the growth of the margin of appreciation doctrine in the ECHR framework, see SAPIENZA, Rosario. Sul margine di apprezzamento statale nel sistema della Convenzione europea dei diritti dell'uomo. Rivista di diritto internazionale, v. 64, p. 589, 1991. See also TOMASI, Laura, Art. 8, in BARTOLE, Sergio; DE SENA, Pasquale; ZAGREBELSKY, Vladimiro. (Ed.), n. 42 above, p. 307; TANZARELLA, Palmina. Il margine di apprezzamento. In: CARTABIA, Marta (Ed.). I diritti in azione. Bologna: il Mulino, 2007. p. 145. 
not involve problems of subsidiarity, because there is not a permanent Court, such as the ECtHR, which - for its superordinate hierarchical position - has the constant power to strongly limit the policy choices which can be made by States. The standards of treatment for foreign investors contained in BITs do not present the structure of the rights contained in the ECHR: in principle, when States violate such standards, they should compensate foreign investors. In conclusion, it does not seem possible to even imagine a way in which the structural conception of the margin of appreciation can find a place in investment arbitration. ${ }^{108}$ Hence, it is no surprise that when arbitral tribunals had the opportunity to evaluate the applicability of the margin of appreciation in international investment law they usually refused that option. ${ }^{109}$ In conclusion, borrowing Gary Born's words in Philip Morris, it is possible to say that the ECHR "was drafted and accepted in a specific geographical and historical context, in relation to a particular human rights instrument. The reasons that led to the acceptance of the "margin of appreciation" in the context of the ECHR are not necessarily transferable to other contexts, including specifically to a BIT". ${ }^{110}$ Confirmation of this approach may be found also in other arbitral awards. In Siemens the Tribunal stated that "article 1 of the First Protocol to the ECHR permits a margin of appreciation not found in customary international law or the [applicable] BIT". ${ }^{111}$ Similarly, in von Pezold, the Tribunal said that "[d]ue caution should be exercised in importing concepts from other legal regimes (in this case European human rights law) without a solid basis for doing so. Balancing competing (and non-absolute) human rights and the need to grant States a margin of

108 A similar conclusion, but partially based on different reasons, has been reached by ARATO, Julian. The Margin of Appreciation in International Investment Law. Virginia Journal of International Law, v. 54, p. 545, 2014. See also TALLENT, Kassi. The Tractor in the Jungle: Why Investment Arbitration Tribunals Should Reject a Margin of Appreciation Doctrine. In: LAIRD, Ian; WEILER, Todd (Ed.). Investment Treaty Arbitration and International Law. Huntington - NY: Juris Net, 2010. v. 3. p. 111; VASANI, Sarah. Bowing to the Queen: Rejecting the Margin of Appreciation Doctrine in International Investment Law. In: LAIRD, WEILER, p. 137. For other critics to the possible applicability of the doctrine in international investment law see ALVAREZ, Jose E; KHAMSI, Kathryn. The Argentine Crisis and Foreign Investors. In: SAUVANT, Karl (Ed.) The Yearbook on International Law and Policy 2008/2009. 2009.p. 440.

109 See Quasar de Valores SICAV S.A. (et al.) v. The Russian Federation, SCC Case No. 24/2007, Award, 20/07/2012, para. 22.

110 Para. 185.

111 Siemens v. Argentina, ICSID Case No. ARB/02/8, Award, 06/02/2007, para. 354 . appreciation when making those balancing decisions is well established in human rights law, but the Tribunal is not aware that the concept has found much support in international investment law". ${ }^{112}$

The discourse is different with regard to the applicability of the a-technical (or substantial) margin of appreciation, which - as we have seen - de facto corresponds to a proportionality analysis of state measures. As it has been correctly stated, ${ }^{113}$ proportionality is an integral part of the fair and equitable treatment standard, which is functional to the ascertainment of the violation of such a standard. Proportionality operates particularly in the cases where it is necessary to balance the legitimate expectations of investors with the sovereign functions of host States. ${ }^{114}$ In this regard, it has

112 Bernhard von Pezold and Others v. Republic of Zimbabwe, ICSID Case No. ARB/10/15, Award, 28/07/2015, paras. 465-466. See also KASTSELAS, Anna. Do Investment Treaties Prescribe a Deferential Standard of Review?. Michigan Journal of International Law, v. 34, p. 139, 2012. The proposed approach finds indirect confirmation also in the scholarship who apparently recognized the applicability of the margin of appreciation in investment arbitration. It is possible to mention, in this regard, BURKE-WHITE, VON STADEN, n. 101 above, p. 324, who said that often "tribunals invoked [the discussed standard] in potentially contradictory ways. In particular, more recent ICSID tribunals have made explicit reference to the least restrictive alternative test, the margin of appreciation and good faith review. The result has been a melding or, perhaps, a confusing of approaches, rather than the emergence of a clear standard of review for public law arbitration". The same Authors, at 328, recognize that "ICSID jurisprudence urgently needs a well-considered analysis of the available standards of review in public law arbitrations and the reasons why a particular standard are appropriate to the public law subject matter of these arbitrations and the text of the treaty being interpreted". These Authors, however, in the end say at 336 that the application proportionality is not the correct way of solving this issue because arbitrators are allegedly ill-suited to carry out this balancing process. The present author disagrees with this statement: first, all deferential doctrines recognize a certain degree of subjectivism to arbitrators and there is no reason to prefer one instead of another. Second, the reason why the parties choose certain arbitrators is exactly their competence and sensibility in solving the specific issues and there is apparently no reason to believe that they would badly carry out their task.

113 PALOMBINO, n. 9 above, p. 164-165. Contrariwise, see XIULI, n. 74 above, p. 639. Palombino's approach as to the inclusion of proportionality as a functional element necessary to verify whether a violation of the fair and equitable treatment took place seems reinforced, inter alia, by the Glamis Gold decision, where the proportionality test was used in order to evaluate whether the investor's legitimate expectations have been violated. See Glamis Gold Ltd. v. United States, UNCITRAL, Award, 08/06/2009, para. 803 Other references are contained in Palombino's book, at $167 \mathrm{f}$.

114 See STONE-SWEET, Alec; MATTHEWS, Jud. Proportionality Balancing and Global Constitutionalism. Columbia Journal of Transnational Law, v. 47, p. 73, 2008, stating that proportionality analysis has become "the preferred procedure [...] for managing [...] 
been correctly noted that the FET itself has a balancing nature and that BITs do not contain absolute rights. ${ }^{115}$ It is possible to mention, in this regard, the Suez award, where - while discussing about the fair and equitable treatment standard - the Tribunal expressly mentioned the balancing process which is typical of the proportionality analysis which is made in domestic constitutional law: "[i]n interpreting the meaning of 'just' or 'fair and equitable treatment' to be accorded to investors, the Tribunal must balance the legitimate and reasonable expectations of the Claimants with [...] (the) right to regulate the provision of a vital public service". ${ }^{116}$ Similarly, in Occidental, the Tribunal determined that "the test [for ascertaining a FET violation] at the end of the day will remain one of overall judgment, balancing the interests of the State against those of the individual, to assess whether the particular sanction is a proportionate response in the particular circumstances". ${ }^{117}$

Obviously, in such a balancing process due weight shall be given to the sovereign functions of the State (requesting Tribunals to be deferential towards States' policy choices) due to the hybrid (public/private) nature of investment arbitration, in which the principle of equality of the parties shall be mitigated by the presence of a sovereign entity. ${ }^{118}$ Deference, therefore, is part of

an alleged conflict between two rights claims, or between a right provision and a legitimate state [...] interest."

115 See HAYNES, Jason. The Evolving Nature of the Fair and Equitable Treatment (FET) Standard: Challenging Its Increasing Pervasiveness in Light of Developing Countries' Concerns - The Case for Regulatory Rebalancing. Journal of World Investment \& Trade, v. 14, p. 114, 2013; VANDEVELDE, Kenneth. A Unified Theory of Fair and Equitable Treatment. New York. University Journal of International Law and Politics, v. 43, p. 43, 2010; DOLZER, Rudolf. Fair and Equitable Treatment: Today's Contours. Santa Clara Journal of International Law, v. 12, p. 7, 2014.

116 Suez, Sociedad General de Aguas de Barcelona S.A. and Interagua Servicios Integrales de Agua S.A. v. Argentina, ICSID Case No. ARB/03/17, Decision on Liability 30/07/2010, para. 216.

117 Occidental Petroleum Corp. v. Republic of Ecuador, ICSID Case No. ARB/06/11, Award, 05/10/2012, para. 417.

118 See HENCKELS, n. 74 above, p. 223; VALENTI, Mara, The protection of general interests of host States in the application of the fair and equitable treatment standard. In: SACERDOTI, Giorgio. The Proliferation of BITs: Conflicts of Treaties, Proceedings and Awards. In: SAUVANT, Karl et al. (Ed.). Appeals Mechanism in International Investment Disputes. Oxford University Press, 2008. p. 35. Analogous considerations on the non-absolute nature of rights conferred to individuals has been made in the ECHR context by CANNIZZARO, n. 9 above, p. 76. Cannizzaro has noted that in the human rights context, as it happens for the FET, the lack of a precise normative definition of certain human rights leaves discretion to States in applying implicit limitations of such rights. In these cases, obviously, the ECtHR has recognized the States' freedom and has the proportionality analysis carried out by arbitrators. Borrowing Saïda El Boudouhi's terminology, ${ }^{119}$ this means that the margin of appreciation "as a concept", i.e. the general recognition of a space of manoeuvre for State authorities, is an implied assumption of the proportionality analysis which finds place in investment arbitration (contrary, as we have seen, to the margin of appreciation "as a doctrine" technically developed by the ECtHR and applicable only in the presence of certain well-defined circumstances).

This has finally led to the emergence of the concept of legitimate expectations by induction, which means that investors can legitimately expect that a State may not amend a particular legal framework without incurring in responsibility only in presence of specific commitments towards them. ${ }^{120}$ Indeed, taking into account the three-pronged structure of proportionality, and in particular the proportionality stricto sensu requirement, ${ }^{121}$ it is possible to say that an investor's legitimate expectations on the stability of a certain legal framework are justified only if and when a State has assumed specific commitments towards such an investor. Indeed, in this latter case a measure violating such commitments is likely to result in a disproportionate violation of the investor's rights, due to the very high level of reliance that the investor put in good faith on the circumstance that the host State legal framework was not going to vary. ${ }^{122}$ In this author's opinion, such a balancing exercise is exactly what the Philip Morris Majority intended

not condemned those limitations. With regard to the concept of deference in investment arbitration see SCHILL, Stephan W. Deference in Investment Treaty Arbitration: Re-conceptualizing the Standard of Review. Journal of International Dispute Settlement, v. 3, p. 577, 2012; CHEYNE, Ilona. Deference and the Use of Public Policy Exceptions in International Courts and Tribunals. In: GRUSZCZYNSKI, Lukasz; WERNER, Wouter. Deference in International Courts and Tribunals. Oxford: Oxford University Press, 2014. p. 38; HENCKELS, Caroline. The Role of Standard of Review and the Importance of Deference in Investor - State Arbitration. In: GRUSZCZYNSKI, Lukasz; WERNER, Wouter. Deference in International Courts and Tribunals. Oxford: Oxford University Press, 2014. p. 113.

119 EL BOUDOUHI, n. 98 above, p. 1-5.

120 See, for a meaningful explanation of the concept of legitimate expectations by induction, as well as for the development of this idea, PALOMBINO, n. 9 above, p. 139 See also PUMA, n. 3 above, p. 232-233.

121 It is worth here recalling that the proportionality stricto sensu analysis requires a concrete evaluation of the proportionality of the goals of the host State in relation to the legal means it has adopted for reaching such goals.

122 See, inter alia, EL BOUDOUHI, n. 98 above, p. 14. for an analysis of the balancing approach of investment tribunals. 
when referring to "margin of appreciation": ${ }^{23}$ Firstly, the Majority recognized that Uruguay's regulations were enacted in the pursuance of the State's public function and, therefore, deserved a certain degree of deference, and, secondly, the Majority stated that, in concreto, they were "reasonable" and not disproportionate when they were adopted and therefore justified a violation of the investors' legitimate expectations. ${ }^{124}$ As better discussed below in this Section, however, the Majority refused to make a careful analysis of the satisfactions of the three prongs of proportionality and this renders the legal path followed in the decision not convincing.

It is also to be noted that Authors who defend the applicability of the margin of appreciation outside the ECHR context never discussed the possibility of applying the features of the doctrine as technically developed by the ECtHR. This seems to be confirmed by the words used by Yuval Shany, who talks about the applicability of "margin of appreciation like doctrines"125 or " "margin of appreciation type' decision making methodology" (emphasis added) outside the ECtHR, thus implictly recognizing that the technical conception of the doctrine cannot find place outside the ECHR framework. ${ }^{126}$ Similarly Burke-White and von Staden merely refer to the margin of appreciation as a theory of deference against State actions, not taking into account all the other elements that compose the technical conception of the doctrine. ${ }^{127}$ These authors expressly acknowledge that "arbitral tribunals have, if less frequently and prominently, applied standards of review similar to the margin of appreciation, often using the term explicitly" (emphasis added). ${ }^{128}$ Finally, El Boudouhi explained that

123 See para. 401.

124 With this particular regard, see paras. 409-410 and 418-420.

125 SHANY, Yuval. All Roads Lead to Strasbourg?: Application of the Margin of Appreciation Doctrine by the European Court of Human Rights and the UN Human Rights Committee. 2017. p. 30. Disponível em: <https://papers.ssrn.com/sol3/papers. cfm?abstract_id $=2925652>$.

126 SHANY, Yuval. Toward a General Margin of Appreciation Doctrine in International Law?. European Journal of International Law, v. 16, p. 928, 2005.

127 BURKE-WHITE, William; VON STADEN, Andreas. Investment Protection in Extraordinary Times: The Interpretation and Application of Non-Precluded Measures Provisions in Bilateral Investment Treaties. Virginia Journal of International Law, v. 48, p. 370, 2008.

128 BURKE-WHITE, William; VON STADEN, Andreas. Investment Protection in Extraordinary Times: The Interpretation and Application of Non-Precluded Measures Provisions in Bilateral Investment Treaties. Virginia Journal of International Law, v. 48, p. 310, 2008. the reference in investment arbitration always occurs to the margin of appreciation "as a concept" (i.e. as a synonymous of deference) and not "as a doctrine" (i.e. as technically developed by the ECtHR). ${ }^{129}$ As the latter mentioned Author explains "it must be stressed again that the mere use of the words 'margin of appreciation' or 'margin of discretion' does not, in itself, amount to the use of the doctrine". ${ }^{130}$ The same happens in the case law. We could start from quoting the Philip Morris decision, where the Tribunal, when referring to the margin of appreciation, merely said that " $[\mathrm{t}]$ he responsibility for public health measures rests with the government and investment tribunals should pay great deference to governmental judgments of national needs in matters such as the protection of public health" ${ }^{131}$ In some other cases Tribunals discussed a margin of appreciation to be granted to host States, but - as noted by Mr. Born in his Dissenting Opinion - a careful reading of the awards reveals that arbitrators were simply saying that it is a duty of Tribunals to apply a deferential standard of review of States' actions. ${ }^{132}$ This is expressly said in Lemire, where the Tribunal made reference to the high level of deference which international law generally extends to the rights of domestic authorities in regulating matters within their own borders, especially in cases where the State's cultural identity is at stake. ${ }^{133}$ Similarly, in Electrabel, the Tribunal had to evaluate whether the introduction of a pricing regulation by Hungary was to be considered as a violation of the fair and equitable treatment standard; Arbitrators recognized the sovereign role of the State in taking this kind of measures and the deference which tribunals owe to sovereign decisions, but avoided any kind of discussion regarding the margin of appreciation. ${ }^{134}$ Finally, in Loewen, Sir Christopher Greenwood stated that "international law allows a broad margin of discretion to each State in the way it organizes its legal system". ${ }^{135}$ As for the other cases, this is a mere reference to States' discretion and not to the 129 EL BOUDOUHI, n. 98 above, p. 15.
130 EL BOUDOUHI, n. 98 above, p. 16.
$131 \quad$ Para. 399.
$132 \quad$ Born's Dissenting Opinion appended to the Philip Morris
award, para. 189.
$133 \quad$ Joseph Charles Lemire $v$. Ukraine, ICSID Case No. ARB/06/8,
Decision on Jurisdiction and Liability, 14/01/2010, para 505.
$134 \quad$ Electrabel $v$. Hungary, ICSID Case No. ARB/07/19, Decision
on Jurisdiction, Applicability and Liability, 30/11/2012, para. 8.35.
135 Loewen $v$. United States, ICSID Case No. ARB(AF)/98/3,
Opinion of Sir Christopher Greenwood appended to the Award,
26/06/2003, para. 65. 


\section{ECtHR doctrine.}

However, as we have tried to demonstrate above, deference is to be considered as a part of the broader proportionality analysis to be carried out in the evaluation of the investors' legitimate expectations. Obviously, the broader will be the wording of the standard of treatment to be applied, the bigger will be the space of manoeuvre for State authorities and the related deference that international arbitrators should pay to State actions in their proportionality analysis. ${ }^{136}$ Indeed, such a deference has been manifested by arbitral tribunals in particular when they had to evaluate violations of broad standards, such as the fair and equitable treatment, alleged caused by States' regulations concerning public services, i.e. those "services which are provided and regulated based on non-commercial public interests and on the need for the provision of such services in a way the market cannot achieve". ${ }^{137}$

Finally, it is worth mentioning the Continental $\mathrm{Ca}$ sualty Company v. Argentina award, ${ }^{138}$ where the Tribunal mentioned the margin of appreciation when referring to the discretion that States enjoy in deciding the contours of their "own security interest". In this regard, it is to be noted that the Tribunal was here applying a BIT provision which expressly authorized Argentina to take measures to protect "its own security interest" and, of course, the same provision allowed the Respondent State to discretionally identify what kind of interests were involved in that category. No reference to the doctrine as developed by the ECtHR is present in the Continental Casualty Company award.

In light of the above, it is worth concluding the present analysis with some final remarks regarding the approach endorsed by the Philip Morris Tribunal. As discussed above, it appears that the Majority of Arbitrators made recourse to the margin of appreciation as a way for paying deference to the measures enacted by the host State. In doing so, it seems that the Philip Morris majority did not apply the technical meaning of the

136 SHANY, Yuval. Toward a General Margin of Appreciation Doctrine in International Law?. European Journal of International Law, v. 16, p. 914, 2005.

137 See KRAJEWSKI, Markus. Investment Law and Public Services. In: BUNGENBERG Marc et al. (Ed.). International Investment Law. Munich: C.H. Beck, 2015. p. 1629. The importance which arbitral tribunals are giving to public services is particularly evident in the above-mentioned Urbaser award, n. 4 above, para. 603.

138 ICSID Case No. ARB/03/9, Award, 05/09/2008, para. 181. margin of appreciation doctrine. However, as explained by Born's Dissenting Opinion, ${ }^{139}$ by refusing to evaluate the concrete suitability of Uruguayans' measures to reach their scope and to carry out a meaningful analysis of the three prongs of proportionality in the present case, the Tribunal seems not to have correctly applied the proportionality analysis which is required in the evaluation of a FET violation. This approach is somewhat confusing and, for this reason, the opinion of the dissenting arbitrator - who suggests the necessity to carry out a meaningful proportionality analysis with respect to the disputed Uruguayan measures - is certainly more shareable.

\section{Final CONCLUSIONS}

The analysis carried out in this article started from the recent decision in the Philip Morris v. Uruguay dispute, where the Tribunal unanimously recognized the existence, the customary status and the applicability by way of systemic interpretation of the so-called police powers (or power to regulate) doctrine and, by majority, recognized that the margin of appreciation doctrine as developed in the ECtHR context - applied in BIT arbitrations. While this decision is certainly to be welcomed for its attempt to take into due consideration the sovereign prerogatives of respondent States in investment arbitration, it does not seem entirely convincing from the point of view of the legal path that Arbitrators decided to follow. Hence, this article has tried to analyze the current status regarding the applicability of the power to regulate, the margin of appreciation and the proportionality principle in investment arbitration.

Concerning the doctrine of the power to regulate we have demonstrated that, as of today, it cannot be considered as a rule of customary international law which can find autonomous application in investment arbitration. It is surely possible to say that existing treaty practice and arbitral case law are establishing a trend towards a broader recognition of this doctrine, but it does not appear equally possible to say that the two requirements of custom, i.e. diuturnitas and opinio juris sive necessitatis, have been met by the police powers doctrine. However, the present paper has tried to show that the sovereign prerogatives of host States can be taken

$139 \quad$ See para. 172. 
into due account by arbitral tribunals when evaluating indirect expropriations through an application of the principle of proportionality, to which the concept of deference towards State authority is inherent.

On the other hand, as to the margin of appreciation doctrine, we have tried to demonstrate that it can be understood both technically, i.e. "as a doctrine" developed by the ECtHR, and "a-technically", i.e. as a synonymous of deference, and that its applicability in investment arbitration depends on how adjudicators understand the concept. The first meaning of margin of appreciation, typical in the ECtHR context, is in direct relationship with the principle of subsidiarity and anchors the applicability of the doctrine to certain specific requirements established by the ECtHR which do not exist in the BIT context. However, the argument has been put forward whereby arbitral tribunals may resort to the margin of appreciation in a substantial (or a-technical) sense, i.e. regarding this doctrine as a balancing technique which involves a deferential approach towards State sovereignty and ends up overlapping with the proportionality analysis.

In conclusion, while the applicability of the police powers and of the margin of appreciation doctrines still appear to be doubtful in investment arbitration, it see$\mathrm{ms}$ that a deeper analysis of the potential applications of the proportionality principle could lead arbitral tribunals to resolve balancing issues and recognize a due level of deference towards States without making recourse to judicial borrowing operations that sometimes turn out to be misleading.

\section{References}

ACCONCI, Pia. The integration of non-investment concerns as an opportunity for the modernization of international investment law: is a multilateral approach desirable?. In: SACERDOTI, Giorgio et al. (Ed.). General Interests of Host States in International Investment Law. Cambridge University Press, 2014. p. 165 f.

ALDRICH, George, What Constitutes a Compensable Taking of Property? The Decisions of the Iran United States Claims Tribunal. American Journal of International Law, v. 88, p. 609, 1994.

ALVAREZ, Jose E; KHAMSI, Kathryn. The Argentine
Crisis and Foreign Investors. In: SAUVANT, Karl (Ed.) The Yearbook on International Law and Policy 2008/2009. 2009. p. 379.

ALVAREZ, Jose E. The Return of the State. Minnesota Journal of International Law, v. 20, p. 223, 2011.

ARATO, Julian. The Margin of Appreciation in International Investment Law. Virginia Journal of International Law, v. 54, p. 545, 2014.

ASCENSIO, Hervé. Article 31 of the Vienna Convention on the Law of Treaties and International Investment Law. ICSID Review - FILJ, v. 31, p. 366, 2016.

BEHARRY, Christina; KURITZKY, Melinda. Going Green: Managing the Environment Through International Investment Arbitration. American University International Law Review, v. 30, p. 426, 2015.

BENVENISTI, Eyal. Margin of Appreciation, Consensus and Universal Standards. New York University Journal of International Law and Politics, v. 31, p. 843, 1999.

BERNARDINI, Piero. Reforming Investor-State Dispute Settlement: The Need to Balance Both Parties' Interests. ICSID Review - FILJ, v. 32, p. 38, 2017.

BESSON, Samantha. Subsidiarity in International Human Rights Law - What is Subsidiarity about Human Rights. The American Journal of Jurisprudence, v. 61, p. 69, 2016.

BJORGE, Eirik. Been There, Done That: The Margin of Appreciation and International Law. Cambridge Journal of International and Comparative Law, v. 4, p. 181, 2015.

BOCCHINI, Francesco. Contributo allo studio del diritto sussidiario. Rome: Aracne Editrice, 2012.

BROWER, Charles H. II, Obstacles and Pathways to Consideration of the Public Interest in Investment Treaty Disputes. Yearbook of International Investment Law and Policy, p. 347, 2008-2009.

BUCHELER, Gebhard. Proportionality in Investor-State Arbitration. Oxford University Press, 2015.

BURKE-WHITE, William; VON STADEN, Andreas. Investment Protection in Extraordinary Times: The Interpretation and Application of Non-Precluded Measures Provisions in Bilateral Investment Treaties. Virginia Journal of International Law, v. 48, p. 307, 2008.

BURKE-WHITE, William; VON STADEN, Andreas. 
Private Litigation in a Public Law Sphere: The Standard of Review in Investor-State Arbitration. Yale Journal of International Law, v. 35, p. 307-308, 2010.

CANNIZZARO, Enzo. Il principio di proporzionalità nell'ordinamento Internazionale. Giuffrè, 2000.

CHEYNE, Ilona. Deference and the Use of Public Policy Exceptions in International Courts and Tribunals. In: GRUSZCZYNSKI, Lukasz; WERNER, Wouter. Deference in International Courts and Tribunals. Oxford: Oxford University Press, 2014. p. 38.

COHEN, Abby; SHANY, Yuval. A Development of Modest Proportions. The Application of the Principle of Proportionality in the Targeted Killing Case. Journal of International Criminal Justice, v. 5, p. 310, 2007.

COLLINS, David. The line of equilibrium: improving the legitimacy of investment treaty arbitration through the application of the WTO's general exceptions. Arbitration International, v. 32, p. 575, 2016.

CONFORTI, Benedetto. Diritto Internazionale. 10. ed. Editoriale Scientifica, 2015.

COTTIER, Thomas et al. The Principle of Proportionality in International Law. NCCR Trade Working Paper No. 2012/38, 2012.

CRAWFORD, Emily. Proportionality. In: WOLFRUM, Rudiger (Ed.). Max Planck Encyclopaedia of Public International Law. 2013. Online version.

DE LUCA, Anna. Indirect expropriations and regulatory takings: what role for the "legitimate expectations" of foreign investors?. In: SACERDOTI, Giorgio et al. (Ed.). General Interests of Host States in International Investment Law. Cambridge University Press, 2014. p. 58.

DI BENEDETTO, Saverio. International Investment Law and the Environment. Edward Elgar, 2013.

DOLZER, Rudolf; BLOCH, Felix. Indirect Expropriation: Conceptual Realignments?. International Law FORUM du droit international, v. 5, p. 155, 2003.

DOLZER, Rudolf. Indirect Expropriation: New Developments?. NYU Environmental Law Journal, v. 64, p. 64, 2002-2003.

DONATI, Filippo; MILAZZO, Pietro. La dottrina del margine di apprezzamento nella giurisprudenza della Corte europea dei diritti dell'uomo. In: FALZEA, Paolo; SPADARO, Antonino; VENTURA, Luigi. (Ed.). La Corte costituzionale e le corti d'Europa. Giappichelli, 2003. p. 65.

EL BOUDOUHI, Saïda. A comparative approach of the national margin of appreciation doctrine before the ECtHR, investment tribunals and WTO dispute settlement bodies. EUI Working Papers RSCAS 2015/27, 2015.

EL BOUDOUHI, Saida. L'intéret general et les règles substantielles de protection des investissements, $A n$ nuaire français de droit international, v. 51, p. 542, 2005

FEINGOLD, Cora. Doctrine of Margin of Appreciation and the European Convention on Human Rights. Notre Dame Law Review, v. 53, p. 90, 1977.

FOOTER, Mary. BITS and Pieces: Social and Environmental Protection in the Regulation of Foreign Investment. Michigan State Journal of International Law, v. 18, p. 33, 2009.

FORTIER, Yves; DRYMER, Stephen. Indirect Expropriation in the Law of International Investment: I Know It When I See It, or Caveat Investor. ICSID Review - FILJ, v. 19, p. 293, 2004.

FRANCK, Susan. The Legitimacy Crisis in Investment Treaty Arbitration: Privatizing Public International Law Through Inconstistent Decisions. Fordham Law Review, p. 1521, 2005.

FRIGO, Manlio. Le limitazioni dei diritti dei privati nel diritto Internazionale. Giuffrè, 2000.

GIARDINA, Andrea. L'arbitrato internazionale in materia di investimenti: impetuosi sviluppi e qualche problema. In: BOSCHIERO, Nerina; LUZZATTO, Riccardo. (Ed.). I rapporti economici internazionali e l'evoluzione del loro regime giuridico. Napoli: Editoriale Scientifica, 2008. p. 319.

GRECO, Roberta. The Impact of the Human Right to Water on Investment Disputes. Rivista di diritto internazionale, v. 98, p. 444, 2015.

GREER, Steven. The margin of appreciation: interpretation and discretion under the European Convention on Human Rights. Strasbourg: Council of Europe Publishing, 2000.

HAN, Xiuli. The Application of the Principle of Proportionality in Tecmed v. Mexico. Chinese Journal of International Law, v. 6, p. 635, 2007.

HANESSIAN, Grand; DUGGAL, Kabir. The Final 2015 Indian Model BIT: Is This the Change the World Wishes to See?. ICSID Review - FILJ, v. 32, p. 216, 2017. 
HEISKANEN, Veijo. The Doctrine of Indirect Expropriation in Light of the Practice of the Iran - United States Claims Tribunal. Journal of World Investment \& Tra$d e$, v. 8, p. 215, 2007.

HENCKELS, Caroline. Indirect Expropriation and the Right to Regulate: Revisiting Proportionality Analysis and the Standard of Review in Investor-State Arbitration. Journal of International Economic Law, v. 15, p. 223, 2012.

HENCKELS, Caroline. Proportionality and Deference in Investor-State Arbitration. Cambridge University Press, 2015.

HENCKELS, Caroline. The Role of Standard of Review and the Importance of Deference in Investor - State Arbitration. In: GRUSZCZYNSKI, Lukasz; WERNER, Wouter. Deference in International Courts and Tribunals. Oxford: Oxford University Press, 2014. p. 113.

HOBER, Kay. Does Investment Arbitration Have a Future?. In: BUNGENBERG Marc et al. (Ed.). International Investment Law. Munich: C.H. Beck, 2015. p. 1873.

HUTCHINSON, Michael. The Margin of Appreciation Doctrine in the European Court of Human Rights. The Internatinoal and Comparative Law Quarterly, v. 48, p. 638, 1999.

ISAKOFF, Peter. Defining the Scope of Indirect Expropriation for International Investments. Global Business Law Review, v. 3, p. 189, 2013.

KASTSELAS, Anna. Do Investment Treaties Prescribe a Deferential Standard of Review?. Michigan Journal of International Law, v. 34, p. 139, 2012.

KLÄGER, Roland. Fair and Equitable Treatment' in International Investment Law. Cambridge: Cambridge University Press, 2011.

KOSKENNIEMI, Martti. It's not the Cases, It's the System. The Journal of World Investment \& Trade, v. 18, p. 343, 2017.

KNAHR, Christina. Indirect Expropriation in Recent Investment Arbitration. Austrian Review of International and European Law, v. 12, p. 85, 2007.

KRAJEWSKI, Markus. Investment Law and Public Services. In: BUNGENBERG Marc et al. (Ed.). International Investment Law. Munich: C.H. Beck, 2015. p. 1629. KRIEBAUM, Ursula. Regulatory Takings: Balancing the Interests of the Investor and the State. Journal of World Investment \& Trade, v. 8, p. 717, 2007.

KUNOY, Bjørn. Developments in Indirect Expropriation Case Law in ICSID Transnational Arbitration. Journal of World Investment \& Trade, v. 6, p. 467, 2005.

LAVRANOS, Nikos. The German Constitutional Court in the Vattenfall Case: Lessons for the ECT Vattenfall Tribunal. 2016. Disponível em: <www.kluwerarbitrationblog.com>.

LETSAS, George. Two Concepts of the Margin of Appreciation". Oxford Journal of Legal Studies, v. 26, p. 705, 2006.

LEVESQUE, Céline. The inclusion of GATTT Article XX exceptions in IIAs: a potentially risky policy. In: ECHANDI, Roberto; SAUVE', Pierre. Prospects in International Investment Law and Policy. Cambridge University Press, 2013. p. 363.

MACDONALD, Ronald St. John. The Margin of Appreciation in the Jurisprudence of the European Court of Human Rights, in International Law at the Times of Its Codification: Essays in Honour of Roberto Ago. Giuffré, 1987. p. 187.

MARKERT, Lars. The Crucial Question of Future Investment Treaties: Balancing Investors' Rights and Regulatory Interests of Host States. European Yearbook of International Economic Law, p. 145, 2011

MARLLES, Justin. Public Purpose, Private Losses: Regulatory Expropriation and Environmental Regulation in International Investment Law. Journal of Transnational Law and Policy, v. 16, p. 275, 2006-2007.

MCLACHLAN, Campbell. The Principle of Systemic Integration and Art. 31(3)(c) of the Vienna Convention. International and Comparative Law Quarterly, v. 54, p. 279, 2005.

MITCHELL, Kate. Philip Morris v. Uruguay: An Affirmation of 'Police Powers' and 'Regulatory Power in the Public Interest' in International Investment Law. EJIL: Talk, 2016.

MONEBHURRUN, Nitish. Novelty in International Investment Law: The Brazilian Agreement on Cooperation and Facilitation of Investments as Different International Investment Agreement Model. Journal of International Dispute Settlement, v. 8, p. 79, 2017.

MONHEBURRUN, Nitish. Is investment arbitration 
an appropriate venue for environmental issues? A Latin American perspective. Brazilian Journal of International Law, v. 10, p. 196, 2013.

MOSTAFA, Bem. The Sole Effects Doctrine, Police Powers and Indirect Expropriation under International Law. Australian International Law Journal, v. 15, p. 279, 2008.

NIGRO, Raffaella. Il margine di apprezzamento e la giurisprudenza della Corte europea dei diritti umani sul velo islâmico. Diritti umani e diritto internaz̧ionale, v. 2, p. 71, 2008.

NIGRO, Raffaella. The Margin of Appreciation Doctrine and the Case-Law of the European Court of Human Rights on the Islamic Veil. Human Rights Review, v. 11, p. 531, 2010.

PADELLETTI, Maria Luisa. Art. 1 Prot. 1. In: BARTOLE, Sergio; DE SENA, Pasquale; ZAGREBELSKY, Vladimiro. Commentario Breve alla Convenzione europea dei diritti dell'nomo. CEDAM, 2012. p. 791.

PALOMBINO, Fulvio Maria. Il trattamento giusto ed equo degli investimenti stranieri, Il Mulino. 2012.

PALOMBINO, Fulvio Maria. Laicità dello Stato ed esposizione del crocifisso nella sentenza della Corte europea dei diritti dell'uomo nel caso Lautsi. Rivista di diritto internazionale, v. 93, p. 134, 2010.

PAPARINSKIS, Martins. The International Minimum Standard and Fair and Equitable Treatment, Oxford: Oxford University Press, 2013.

PAULSSON, Jan. The Power of States to Make Meaningful Promises to Foreigners. Journal of International Dispute Settlement, v. 1, p. 341, 2010.

PAVONI, Riccardo. Environmental Rights, Sustainable Development, and Investor-State Case Law: A Critical Appraisal. In: DUPUY, Pierre-Marie; PETERSMANN, Ernst-Ulrich; FRANCIONI, Francesco. (Ed.). Human Rights in International Investment Law and Arbitration. Oxford University Press, 2009. p. 525.

PELLET, Alain. Police Powers or the State's Right to Regulate. In: KINNEAR, Meg et al. (Ed.). Building International Investment Law: The First 50 Years of ICSID, Kluwer Law International. 2015. p. 447.

PINO, Giorgio. Conflitto e bilanciamento tra diritti fondamentali: Una mappa dei problemi. Etica e politica, v. 8, p. 1, 2006.
PUMA, Giuseppe. Human Rights and Investment Law: Attempts at Harmonization Through a Difficult Dialogue Between Arbitrators and Human Rights Tribunals. In: ARCARI, Maurizio; BALMOND, Louis. (Ed.). Judicial Dialogue in the International Legal Order. Editoriale Scientifica, 2014. p. 193.

PUPOLIZIO, Ivan. The Right to an Unchanging World - Indirect Expropriation in International Investment Agreement and State Sovereignty. Vienna Journal of International Constitutional Law, v. 10, p. 143, 2016.

RAGNI, Chiara. Standard of Review and the Margin of Appreciation Before the International Court of Justice. In: GRUSZCZYNSKI, Lukasz; WERNER, Wouter. Deference in International Courts and Tribunals. Oxford: Oxford University Press, 2014. p. 319.

RATNER, Steven R. Compensation for Expropriation in a World of Investment Treaties: Beyond the Lawful/ Unlawful Distinction. 2017. Disponível em: < https:/ / ssrn.com/abstract $=2954146>$.

RATNER, Steven. Regulatory Takings in Institutional Context: Beyond the Fear of Fragmented International Law. American Journal of International Law, v. 102, p. 475, 2008.

REISMAN, W Michael. The Empire Strikes Back: The Struggle to Reshape ISDS. 2017. p. 12. Disponível em: $<$ https://papers.ssrn.com/sol3/papers.cfm?abstract_ id $=2943514>$.

ROBERTS, Anthea. Clash of Paradigms: Actors and Analogies Shaping the Investment Treaty System. American Journal of International Law, v. 107, p. 45, 2013.

RUBINI, Luca. L'impatto del GATS sulla regolazione nazionale dei servizi di interesse generale. Diritto del commercio internazionale, v. 21, p. 373, 2007.

RUSSO, Deborah. Sull'uso della ragionevolezza dap arte della Corte internazionale di giustizia nel controllo sull'esercizio dei poteri discrezionali degli stati. Rivista di diritto internazionale, v. 98, p. 487, 2015.

SACERDOTI, Giorgio. The Proliferation of BITs: Conflicts of Treaties, Proceedings and Awards. In: SAUVANT, Karl et al. (Ed.). Appeals Mechanism in International Investment Disputes. Oxford University Press, 2008. p. 133.

SALERNO, Francesco. Il vincolo al rispetto dei diritti dell'uomo nel sistema delle fonti del diritto internazionale privato. Diritti umani e diritto internazionale, v. 8, p. 
556, 2014.

SAPIENZA, Rosario. Sul margine di apprezzamento statale nel sistema della Convenzione europea dei diritti dell'uomo. Rivista di diritto internazionale, v. 64, p. 571, 1991.

SAUL, Matthew. The European Court of Human Rights' Margin of Appreciation and the Processes of National Parliaments. Human Rights Law Review, v. 15, p. 745, 2015.

SCHILL, Stephan W. Deference in Investment Treaty Arbitration: Re-conceptualizing the Standard of Review. Journal of International Dispute Settlement, v. 3, p. 577 , 2012.

SCHREUER, Christoph; KRIEBAUM, Ursula. From Individual to Community Interest in International Investment Law. In: FASTENRATH, Ulrich et al. (Ed.). From Bilateralism to Community Interest. Essays in Honour of Judge Bruno Simma. Oxford University Press, 2011. p. 1079.

SCHULTZ, Thomas; DUPONT, Cédric. Investment Arbitration: Promoting the Rule of Law or Over-Empowering Investors? A Quantitative Empirical Study. European Journal of International Law, v. 25, p. 1147, 2014.

SHANY, Yuval. All Roads Lead to Strasbourg?: Application of the Margin of Appreciation Doctrine by the European Court of Human Rights and the UN Human Rights Committee. 2017. p. 1. Disponível em: $<$ https://papers.ssrn.com/sol3/papers.cfm?abstract_ $\mathrm{id}=2925652>$.

SHANY, Yuval. Toward a General Margin of Appreciation Doctrine in International Law?. European Journal of International Law, v. 16, p. 907, 2005.

SIMMA, Bruno; KILL, Theodore. Harmonizing Investment Protection and International Human Rights: First Steps Towards a Methodology. In: BINDER, Christina (et al.). International Investment Law for the 21st Century: Essays in Honour of Christoph Schreuer. Oxford University Press, 2009. p. 678.

SORNARAHAH, Mutucumaraswamy. Resistance and Change in the International Law of Foreign Investment. Cambridge: Cambridge University Press, 2015.

STAIANO, Fulvia. (In)Comparable Situations: Same-Sex Couples' Right to Marriage in European Case Law. 2017. Disponível em: < diwww.federalismi.it>.
STONE SWEET, Alex; DELLA CANANEA, Giacinto. Proportionality, General Principles of Law, and Investor-State Arbitration: A Response to Jose Alvarez. NYU Journal of International Law and Politics, v. 46, p. 911.

STONE-SWEET, Alec; MATTHEWS, Jud. Proportionality Balancing and Global Constitutionalism. Columbia Journal of Transnational Law, v. 47, p. 73, 2008.

TALLENT, Kassi. The Tractor in the Jungle: Why Investment Arbitration Tribunals Should Reject a Margin of Appreciation Doctrine. In: LAIRD, Ian; WEILER, Todd. (Ed.). Investment Treaty Arbitration and International Law. Huntington - NY: Juris Net, 2010. v. 3. p. 111.

TANZARELLA, Palmina. Il margine di apprezzamento. In: CARTABIA, Marta. (Ed.). I diritti in azione. il Mulino, 2007. p. 145.

TANZI, Attila. On Balancing Foreign Investment Treaties with Public Interests in Recent Arbitration Case Law in the Public Utilities Sector. The Law and Practice of International Courts and Tribunals, v. 11, p. 47, 2012.

TESAURO, Giuseppe. Nazionalizzazioni e diritto Internazionale. Edizioni Scientifiche Italiane, 1976.

TITI, Aikaterini. Refining the Expropriation Clause: What Role for Proportionality?. 2017. p. 1. Disponível em: $<$ https://papers.ssrn.com/sol3/papers.cfm?abstract_ id $=2978530>$.

TITI, Aikaterini. The Right to Regulate in International Investment Law. Oxford: Hart, Nomos, Dike, 2014.

TOMASI, Laura. Art. 8. In: BARTOLE, Sergio; DE SENA, Pasquale; ZAGREBELSKY, Vladimiro. (Ed.). Commentario Breve alla Convenzione europea dei diritti dell'uomo. CEDAM, 2012. p. 307.

TREVES, Tullio. Customary International Law, Max Planck. Enciclopedia of Public International Law. 2010. Disponível em: <www.mpepil.com>.

TUDOR. The Fair and Equitable Treatment Standard in International Investment Law. Oxford: Oxford University Press, 2008.

VADI, Valentina; GRUSZCZYNSKI, Lukasz. Sandards of Review in International Investment Law and Arbitration: Multilevel Governance and the Commonweal. Journal of International Economic Law, v. 16, p. 613, 2013.

VALENTI, Mara. The protection of general interests of host States in the application of the fair and equitable treatment standard. In: SACERDOTI, Giorgio 
et al. (Ed.). General Interests of Host States in International Investment Law. Cambridge University Press, 2014. p. 26.

VAN HARTEN, Gus. Investment Treaty Arbitration and Public Law. Oxford: Oxford University Press, 2007.

VASANI, Sarah. Bowing to the Queen: Rejecting the Margin of Appreciation Doctrine in International Investment Law. In: LAIRD, Ian; WEILER, Todd (Ed.). Investment Treaty Arbitration and International Law. Huntington - NY: Juris Net, 2011. v. 3. p. 137.

VILLIGER, Mark. Customary International Law and Treaties. Martinus Nijhoff Publishers, 1985.

VOON, Tania. Philip Morris v. Uruguay: Implications for Public Health. Journal of World Investment and Trade, v. 18, p. 320, 2017.

WAGNER, Markus. Regulatory Space in International
Trade Law and International Investment Law. University of Pennsylvania Journal of International Law, v. 36, p. 1, 2015.

WÄLDE, Thomas; KOLO, Abba. Environmental Regulation, Investment Protection and 'Regulatory Taking in International Law. The International and Comparative Law Quarterly, v. 50, p. 811, 2001.

YANNACA-SMALL, Catherine. "Indirect Expropriation" and the "Right to Regulate" in International Investment Law. OECD Working Papers on International Investment Number 2004/4, 2004.

YOUROW, Howard Charles. The Margin of Appreciation Doctrine in the Dynamics of European Rights Jurisprudence. Connecticut Journal of International Law, v. 3, p. 118, 2011. 
Para publicar na Revista de Direito Internacional, acesse o endereço eletrônico www.rdi.uniceub.br ou www.brazilianjournal.org.

Observe as normas de publicação, para facilitar e agilizar o trabalho de edição. 